\title{
A TERÜLETI TERVEZÉS KIHÍVÁSAI A KILENCVENES ÉVEKBEN MAGYARORSZÁGON: A TERÜLETFEJLESZTÉSI STRATÉGIÁK KIALAKÍTÁSÁTÓL A PROGRAMOZÁSIG ÉS AZ ÉRTÉKELÉSIG
}

(Challanges of the Spatial Planning in Hungary in the 1990s: from Regional Strategies to Programming and Impact Analysis)

\section{LADOS MIHÁLY}

Kulcsszavak:

területi tervezés területfejlesztés EU csatlakozás fejlesztési koncepciók, programok

A tanulmány a megyei, a regionális, a nemzeti és a nemzetközi szintü tervekkel foglalkozik. A tanulmány középpontjában az áll, hogy az EU csatlakozással összefüggésben milyen kihivások érték érik a ha=ai területi terve=ést és az annak való megfelelés folyamatába a NYUTI milyen módon kapcsolódott be, mennyiben volt képes szerepet játszani a hazai területi tervezés megújitásában, az innovativ móds=erek terjesstésében.

A tanulmány négy nagyobb témakörre bontva tárgyalja ezt a megfelelési folyamatot. Az elsó blokk a területi tanulmányokkal kapcsolatos igények átalakulását tárgyalja a nyolcvanas évek végén. A második blokk a tervezési rendszer megújitásának az EU csatlakozásból és Maastricht-i szerzödésböl fakadó követelményeibỏl, a stratégiai tervezés módszerének hazai megalapozásából indul ki. A harmadik blokk a konzorciumban való együttmüködés és a projektek nemzetkö̈i szintre emelkedését tárgyalja. A negyedik blokk a= elöcsatlakozási idöszak nagy kihivásával a programozással foglalkozik.

A hazai társadalmi-gazdasági átalakulás, a rendszerváltás során a tervezés, benne a területi tervezés, a korábbi rendszer egyik szimbólumaként jelent meg. Ezért a rendszerváltók megszüntették a tervezés intézményi hátterét mind nemzeti (Országos Tervhivatal - OT és annak háttér-kutatóintézete, az OT Tervgazdasági Intézet - OT TGI), mind megyei szinten (megyei tanácsok tervosztályai'). Ami megmaradt, az a területrendezési tervezés 1980-as évek végére decentralizálttá váló rendszere (VÁTI, megyei tervezó vállalatok, szaporodó magán tervezó szervezetek), néhány megyei önkormányzatnál önként vállalt feladatként egy kis létszámú területfejlesztési csoport (pl. Győr-Moson-Sopron megye) és a területi folyamatokat kutató, azt multidiszciplináris módon elemző, vizsgáló akadémiai kutatóintézet, az 1980-as évek közepén országos hálózattá fejlődött MTA Regionális Kutatások Központja (RKK).

Magyarország 1991-ben az Európai Unió (EU) társult tagja lett, és az 1990-tỏl indított PHARE segélyprogramon keresztül megkezdte felkészülését a csatlakozásra. Külön csomag segítette a területi politika EU konform átalakítását. A területfejlesztéssel foglakozó szakemberek gyorsan szembesültek azzal, hogy az uniós regionális politika erósen támaszkodik a tervezés, mégpedig egy megújított területi tervezés, a stratégiai tervezés ${ }^{2}$ eszközeire. A kilencvenes évek így a tervezés reneszánszaként jeleníthető meg Magyarországon (1. táblázat), de érvényes ez a tagországokra és a csatlakozásra várókra egyaránt. 


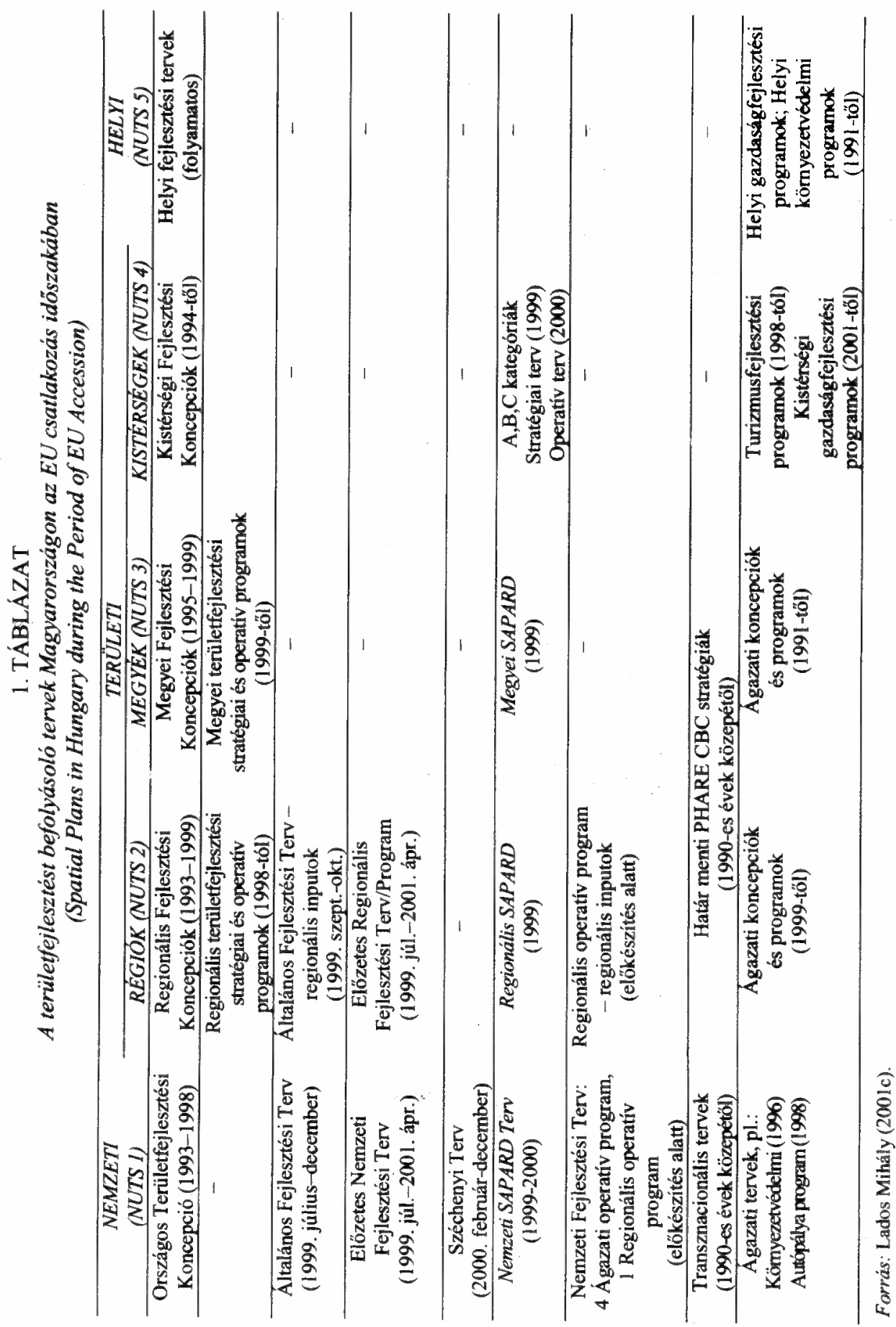


Az időben haladva, a nagy ivü koncepciók készítésétöl napjainkra a részletes, projekt javaslatokkal alátámasztott operativ programokig jutottunk el. Ez a folyamat nem csupán nemzeti szinten, hanem a területfejlesztésnek az 1990-es évtized során kialakult, majd az 1996. évi XXI. Területfejlesztési törvényben is rőgzített valamennyi - regionális, megyei, kistérségi, helyi - szintjén végigfutott. Természetesen az egyes fázisok időben kicsit eltolva jelentkeztek az egyes szinteken, de ez már magából a hazai területfejlesztés intézményesülésének időbeni széthúzódásából adódik. Az egyes szinteken párhuzamosan futó, egyre gyakrabban partnerségi alapon, alulról szerveződő, társadalmasított tervezésbe az ezredfordulóra már több ezren kapcsolódtak be. Ennek formái rendkíviul változatosak lehettek, a szakértỏi-kutatói munkától a munkamegbeszéléseken (workshop-okon) való részvételen át a (kötelező) egyeztetési eljárás során adott írásos véleményig.

Ebben a sokszereplös, egyre bövüló kört érintö folyamatban az RKK, és azon belül a Nyugat-magyarországi Tudományos Intézet (NYUTI) is úttörỏ szerepet játszott, hiszen a területfejlesztés valamennyi szintjén az elsők kőzött kapcsolódott be a tervezési rendszer megújitásába. A tanulmány a fent jelzett folyamatot kívánja megragadni, mégpedig a NYUTI szemüvegén át, a NYUTI által végzett területi tervezési munkák áttekintésén és értékelésén keresztül.

A tanulmány a megyei, a regionális, a nemzeti és a nemzetközi szintü tervekkel foglalkozik. A kistérségi tervek, azok nagy száma és a NYUTI-n belül ơnálló irányként való megjelenése miatt egy másik tanulmányban kerülnek feldolgozásra. A tanulmány középpontjában az áll, hogy az EU csatlakozással összefüggésben milyen kihivások érték érik a hazai területi tervezést és az annak való megfelelés folyamatába a NYUTI milyen módon kapcsolódott be, mennyiben volt képes szerepet játszani a hazai területi tervezés megújításában, az innovatív módszerek terjesztésében.

A tanulmány négy nagyobb témakörre bontva tárgyalja ezt a megfelelési folyamatot. Az első blokk a területi tanulmányokkal kapcsolatos igények átalakulását tárgyalja a nyolcvanas évek végén. A második blokk a tervezési rendszer megújításának az EU csatlakozásból és a Maastricht-i szerződésből fakadó követelményeiből, a stratégiai tervezés módszerének hazai megalapozásából indul ki. A harmadik blokk a konzorciumban való együttmủködés és a projektek nemzetközi szintre emelkedését tárgyalja. A negyedik blokk az elócsatlakozási időszak nagy kihívásával, a programozással foglalkozik.

\section{A területi tanulmányokkal kapcsolatos igények átalakulása: kutatási megrendelők megjelenése a területfejlesztésben}

A nyolcvanas évek második felében és az évtizedváltás időszakában megváltoztak, átalakultak a társadalomtudományi és ezen belül a területi kutatásokkal kapcsolatos igények. A tudományos alapokon kívủli megrendelök belépésével (pl. különbőzỏ minisztériumok, megyei tanácsok, helyi tanácsok) a hagyományos leíró, monografikus tanulmányok kiegészültek olyan fejlesztési 
javaslatokkal, amelyek konkrét területpolitikai akciókat, illetve fejlesztési projekteket alapoztak meg.

A NYUTI alapítási sajátosságai következtében már az indulás éveitől ilyen környezetben dolgozott. A Győrben 1986-ban létrehozott új RKK-s egység az MTA és Györ-Sopron Megyei Tanács hosszú távú együttmüködése keretében kezdte meg múködését. Ez a gyakorlatban azt jelentette, hogy az új kutatási egység forrásainak mintegy $80 \%$-át a megye biztositotta a kezdetekkor. A megyénél a haszon oldalon egy éves egyeztetés alapján - a megye egészére vagy valamely térségére készített tanulmány jelent meg.

Az akadémiai finanszírozás szúkössége, illetve a nemzeti kutatási alapoktól (AKA, OTKA, Fiatal OTKA, TS-II) elnyerhető mérsékelt támogatások a környezettel való szorosabb egyutttmüködésre ösztönözték a NYUTI-t. Így vált az intézet munkáinak szinte folyamatos megrendelỏjévé a Gazdasági Minisztérium (GM) akkori elődszervezete az Ipari Minisztérium (IM), és született egy három éves kutatási együttmúködés a Komárom-Esztergom Megyei Tanáccsal (1998-1990).

A tudományos alapoktól eltérően, melyek futamideje rendszerint 2-4 év, az új partnerek számára készủlő munkák átfutási ideje 1 év volt. Ez jelentôsen lerövidítette a kutatásokban az egyes munkafázisokra fordítható addig szokásos idókereteket. Módszereit tekintve ezek a kullső megbízók számára készüló kutatások a klasszikus társadalomtudományi kutatási módszertant követték: alapos irodalom feltárás, statisztikai adatbázisok gondos feldolgozása, interjúkkal és kérdóivekkel lebonyolított empirikus kutatások, amely az adott terület széles körü helyzetfeltárását eredményezte. A többletet az adta, hogy a helyzet bemutatásán, az összefüggések feltárásán túl a megrendelök beavatkozási javaslatokat is vártak a kutatóktól a hiányok, a szủk keresztmetszetek feloldására.

1986 és 1992 között a NYUTI mintegy 15 „külső megbizással” megvalósuló kutatást végzett, melyek hatóköre döntően az Észak-Dunántúl, a nyugati határ mente, illetve néhány esetben az ország egész területe volt. Ezek listáját az Irodalomjegyzék tartalmazza. Három, a megrendelöket tekintve eltérő kutatást emelnénk ki ebből a körből:

- A Rábaköz térszerkezete (1987-1988);

- A gazdasági és szellemi erőforrások innováció-orientált fejlesztése az osztrákmagyar határ menti régiókban (1989-1990);

- Az innováció fogadás feltételei Vas megye hátrányos helyzetủ mikrotérségeiben (1990-1991).

\section{A Rábaköz térszerkezete}

A NYUTI alakulását követỏ év a megye feltérképezésével telt el. Elindultak a megye térszerkezetét feltáró vizsgálatok a természeti környezet, a népesedési folyamatok, a gazdaság, az infrastruktúra, a településközi kapcsolatok területén (Rechnitzer-Sas 1987). A megyei politikában és irányításban előtérbe került azon erôforrások elemzése, értékelése, amelyek segíthették a társadalmi-gazdasági 
kibontakozást. Ezekben a törekvésekben az egyes térségek, tájegységek, egybetartozó település-együttesek is lényeges szerepet játszanak. Adottságaik feltárásával és széles körủ megismertetésével nemcsak a megye értékei gyarapithatók, hanem az ott éló lakosság önismerete is bővíthetö.

A megyei támogatás keretei között az 1987. évben induló kutatás meghatározásakor a választás a Rábaközre, a megye egyik történelmi és néprajzi hagyományokban bövelkedỏ tájegységére esett. A kutatás többirányúan közelítette a térséget, hiszen a földrajzi, környezeti tényezöktöl kezdve, a gazdasági potenciál értékelésén át, a népességi és infrastrukturális viszonyokig elemezte a Rábaközt és településeit, rámutatva Csorna és Kapuvár térségszervező funkcióira.

A kis létszámú, fiatal kutatócsoport a sokrétủ munka elvégzéséhez elismert helyi kutatók közremüködését nyerte meg. Így a Rábaköz tanulmánykötet (Rechnitzer 1988) természetföldrajzi fejezetét Göcsei Imre földrajz-, a gazdaságtörténetit pedig Timaffy László néprajztudós írta meg. A feltáró munka nagymértékben támaszkodott a Gyốr-Sopron megyei Könyvtár rendkívül gazdag helytörténeti irodalmára,' valamint a Rábaköz valamennyi telepưlését (54 község és 2 város) érintő terep bejárására. A kutatócsoport valamennyi tanácselnökkel és gazdasági vezetővel személyes interjút készített, de nem maradtak ki a megkérdezésből az oktatási intézmények és kulturális csoportok vezetöi sem. Igaz a nyolcvanas évek végi centralizált igazgatási (tanácsi- és iskolai körzetek) és gazdasági (mezőgazdasági termelőszövetkezeti, ÁFÉSZ és takarékszövetkezeti körzetek) szervezetrendszerében a ténylegesen megkérdezhető szervezetek száma alig haladta meg a Rábaköz összes településének a számát.

A kutatás Mihályiban helyi államigazgatási, politikai és gazdasági vezetők részvételével megtartott záró vitája egy 20 pontból álló ajánlás listát fogadott el a Rábaköz fejlesztésére, melyek közül máig helytállóan az alábbiak emelhetők ki (Rechnitzer 1988, 202-204):

"...

4) A mezőgazdaságot a térségben munkaerö felszabadító ágazatnak kell tekinteni. ... a jövöben tovább csökken a mezőgazdasági munkahelyek száma, ami a Rábaköz foglalkoztatási feszültségeit még hangsúlyozottabbá teszi.

...

6) ... Kívánatosnak látszik zöldség- és gyümölcsfeldolgozó vagy elö-feldolgozó kisüzemek létrehozása ....

10) A térség foglalkoztatási feszültségeit a kiépítendỏ bedolgozói és kisüzemi rendszerekkel oldani lehet. Ezen szervezetek kapcsolódhatnak a mezocentrumok iparához, gazdaságához (háttéripar vagy részegység elóállítás, összeszerelés stb.), de részt vállalhatnak a mikroközpontok ipari szervezeteinek hatékonyabb és sokoldalúbb (alapanyag, résztermék előkészítés, helyi termelési kultúrák felélesztése, népmủvészet, háziipar stb.) bỏvítésében is.

11) Az idegenforgalom csak potenciális bázisa lehet a térség fejlesztésének. A mezocentrumokban megindult a gyógyturizmus feltételeinek kialakítása, aminek 
számottevő foglalkozatási hatása egyenlöre még nem lesz. A falusi turizmus lehetőségei csak részben adottak a Rába menti településekben (kedvezötlen infrastruktúra, fogadókészség hiánya). A térségben vannak olyan objektumok (vízimalom, átalakítható gazdasági épületek, elhagyott ingatlanok), amelyek az átmenö forgalom idöszakos megállítására már alkalmasak lehetnek. Az idegenforgalmi kisvállalkozások eröteljes támogatásával több településben kedvezỏ hatás érhető el.

...

14) A gyenge, periférikus jellegủ infrastruktúrával rendelkezỏ településeken a falugondnok intézményének felállítása célszerủ. ...

15) A kisközponti funkciók életképességének növelése megkívánja a térségi közlekedési kapcsolatok bővítését, minőségük javítását. ... ...

20) A térség gazdasági potenciáljának és foglalkoztatási viszonyainak bövítésére a központi és helyi eröforrásokból Rábaközi Innovációs Alapot kell létrehozni..."

A Rábaköz tanulmány és az azt megelözö megyei térszerkezeti vizsgálatok összességében felhívták a figyelmet arra, hogy az országos összehasonlításban fejlettnek számító Györ-Sopron megyén belül számos területi, térszerkezeti feszültség húzódik meg. A kisvárosok szervezö ereje a megye közép- és nagyvárosaihoz képest mérsékelt, a 85-ös főúttól délre elhelyezkedỏ területek városhiányos, periférikus, elmaradott jegyeket mutatnak. Bár Györ-Sopron megye egyetlen térsége sem került be a kormány által 1986-ban indított elmaradott térségek felzárkóztatási programjába, ezek a kutatások jelezték, hogy a megye déli sávja azokhoz hasonló kedvezötlen társadalmi-gazdasági mutatókkal rendelkezik. Csak a Területfejlesztési törvény hatályba lépésével induló Területi Kiegyenlítési Alap (TEKI) kedvezményezett településeinek meghatározásakor került be az elmaradott térségek körébe a Rábaköz egy-egy része (1996-ban a Kapuvári, majd 1997-től a Csornai KSH kistérség ${ }^{3}$ ).

\section{A gazdasági és szellemi erőforrások innováció-orientált fejlesztése az osztrák-magyar határ menti régiókban}

Az osztrák-magyar határ két oldalán elhelyezkedő régiók, az azokat alkotó államigazgatási egységek példamutató együttmükődése alapozta meg ezt az 1989_ 1990-ben lezajlott innováció-orientált határ menti területfejlesztést segítő vizsgálatot. Ez egyben a NYUTI elsö nemzetközi kutatása is volt. A háttérfeltételeket magyar oldalon a Győr-Sopron Megyei Tanács éves támogatása és az Észak-dunántúli Regionális Gazdasági Kamara (kutatási megbeszélések helyszíne), míg osztrák oldalon a Burgenlandi Munkaügyi Kamara biztosította. A NYUTI és osztrák partnere, a bécsi székhelyủ Österreichiches Institut für Berufbildungsforschung (ÖIBF) sokoldalú vizsgálatokkal kísérelte meg feltárni a 
két határ menti térség nyolcvanas évek végi gazdasági és foglalkoztatási szerkezetének azonosságait és különbségeit.

Burgenland Ausztria periférikus elhelyezkedésủ határ menti tartománya, amelynek felzárkóztatását a határon átnyúló gazdasági együttmüködések is segíthetik. A Nyugat-Dunántúl ugyanakkor a magyar átlagnál kedvezőbb gazdasági szerkezettel, iskolázottabb és képzettebb népességgel és jobb infrastrukturális felszereltséggel rendelkezik. Az országon belüli fejlettsége azonban relatív, hiszen a térségen belül is számos területi feszültség volt érzékelhetö, míg az „elmaradott szomszéd" gazdasági-ellátottsági mutatói többnyire a magyar oldalt meghaladóak voltak.

A hagyományos térségi vizsgáltok az ellátottságra, az infrastrukturális viszonyokra terjedtek ki. Természetesen a kutatás ezt a „kötelező feladatot” teljesítette, azonban ủj utakat is keresett. Nemcsak a mennyiségi erőforrásokat elemezte, hanem megkísérelte a határ menti térségek gazdaságának, településhálózatának minóségi faktorait is számba venni. A választott út járatlan volt, hiszen a térségek gazdaságát az innovációs potenciál, a megújitási képesség jelenléte alapján próbálta meg elemezni.

A kutatás két célt igyekezett teljesíteni. Egyrészt megkísérelte feltárni egy valós piacgazdaságban és egy átmeneti gazdaságban az innovációs magatartás alapvetỏ faktorait, ezzel értelmezni a megújitás, a modernizáció lehetséges módozatait, bejárható útjait és motiváló faktorait. Másrészt igyekezett kimutatni a két ország szomszédos térségeiben a gazdasági fejlödés irányait, keresve a lehetséges csomópontokat az együttmüködésre, a jövőbeli esetleges integrációra (Rechnitzer 1990).

A vizsgálatok magyar oldalon Györ-Sopron megye és Vas megye meghatározó gazdasági egységeiben egy kérdöíves felmérés segítségével keresték a modernizáció módjait, a termelési és tevékenységi formák átalakulásának formációit, egy új, a korábbitól eltérő fejlődési pálya kiinduló pontjait. A határ túloldalán az osztrák kollégák hasonló tematikával, módszerekkel tették ugyanezt.

A kutatás közösen kidolgozott ajánlásokat fogalmazott meg a gazdaság és a területfejlesztési politika formálói számára. A javaslatok középpontjában a lehetséges határ menti gazdasági együttmüködések voltak, amelyek új dimenzióba helyezhetik a vizsgált térségek fejlódését, innovációs adottságaik aktivizálását.

A kilencvenes évek folyamán az osztrák és azon belul a burgenlandi kis- és középvállalkozások részvétele a nyugat-dunántúli gazdaság privatizálásában és zöldmezős beruházásaik jelentősen segítették a térség gazdasági modernizációját. Ausztria EU taggá válását követően, az 1995-1999 között múködő INTERREGPHARE CBC program segítségével pedig a Nyugat-Dunántúl az EU területfejlesztési politikájának közvetlen minta területévé vált. Ebben szintén kulcsszerepet kapott a gazdasági együttmüködés. A fenti folyamatok kedvezö alakulásához talán egy kis téglát a fenti közös kutatás is hozzátett. 
Lados Mihály: A területi tervezés kihívásai a kilencvenes években Magyarországon:

A területfejlesztési stratégiák kialakitásáról a programozásig és az értékelésig. Tér és Társadalom, 15. 2001. 2. 25-69. p

\section{Az innováció fogadás feltételei Vas megye hátrányos helyzetü mikrotérségeiben}

Ez a kutatás egy osztrák-magyar területfejlesztési know-how program indítását segítette. A piacgazdaságra való áttérést a centralizált struktúrák és a vállalkozások hiánya nehezítette. Az átalakulás gyakran a munkanélküliség és az egyes régiók közötti fejlödési különbségek növekedésével jár. Különösen igaz ez olyan térségekre, amelyek az átalakulás indítórajtjánál is az elmaradottság jegyeit mutatják. A Vas megye déli részén elhelyezkedő mikrotérségek az 1986-ban nemzeti szinten inditott elmaradott térség program célterületei voltak.

Ez a kiindulási helyzet párhuzamot mutatott a fejlett ipari országok hátrányos régióinak helyzetével. Ott is több esetben hiányzott a vállalkozói tapasztalat, a vállalkozáshoz való bátorság - és az ismeretek arról, hogy hogyan lehet a helyzetet megváltoztatni. A hátrányos helyzetủ térségek megmozdításában egyre elterjedtebbé vált az „önálló regionális fejlesztés” koncepciója. Ennek elméleti alapjait az endogén fejlödési modell dolgozta ki (Rechnitzer 1994). Az új területi politikák homlokterébe a térségek, a régiók adottságai kerültek, amelyek a fejlesztésekhez mint belső, endogén erőforrások állnak rendelkezésre, és megfelelö körülmények között aktivizálhatók.

Ez az elmaradott térségek fejlesztésének egy olyan stratégiája, amely a meglévó forrásokra és lehetőségekre épít. Az önállóság ebben az összefüggésben azt jelenti, hogy a térség fejlödését elsősorban az ott élő embereknek, az ő tudásuknak és képességeiknek kell meghatározni. Ennek megfelelően megkülönböztetett figyelem irányul a már meglévö ötletek vizsgálatára és megvalósitására, valamint a helyi kezdeményezések támogatására.

Ausztriában a nyolcvanas évek folyamán sikeresnek bizonyult a modell alkalmazása. Ezt egy regionális intézményhálózat, egy decentralizált tanácsadói hálózat kialakítása alapozta meg. Ezek az ,intermedier” szervezetek közvetítőként tevékenykedtek a regionális kezdeményezések és a politikai adminisztrációs renđszer (közigazgatás, támogatási helyek stb.) között, gondoskodtak a szintek közötti jobb információáramlásról.

A magyar és az osztrák felelős szervek (KTM, Vas Megyei Önkormányzat, Osztrák Kancellária Hivatal, Osztrák-Magyar Teruletfejlesztési Kormányközi Bizottság) az „önálló regionális fejlesztés” Ausztriában alkalmazott modelljét egy kísérleti program keretében Vas megyében kívánták a magyar viszonyok között adaptálni. A szervezeti kereteket a Vas Megyei Elmaradott Térségi Önkormányzatok Szövetsége (VETÖSZ), melyet 93 helyi önkormányzat alapított, és a VETÖSZ által Vasváron létrehozott REGINNOV tanácsadó iroda adta. Az osztrák ÖAR-Regionalberatung egy know-how program keretében két éven keresztül képezte a REGINNOV hat munkatársát havi egyhetes workshopok keretében a helyi kezdeményezéseken alapuló fejlesztések menedzselésére.

A know-how program részeként, az osztrák szervezet a NYUTI-t bízta meg olyan térségfelmérés elkészitésével, amely a REGINNOV tanácsadó munkáját hivatott 
megalapozni. A felmérésnek be kellett mutatnia Vas megye elmaradott térségeinek gazdasági és szociális helyzetét, rá kellett mutatnia a térség gyengeségeire és hiányossâgaira, fel kellett tárnia a kedvező adottságokat.

A térség alapos feltérképezését egy háromhetes terepbejárás alapozta meg. A NYUTI-s csapat hetente váltva a táborhelyét településről településre (79 község, 3 város) bejárta az érintett térséget a Vendvidéktöl az Örségen, a Rába-völgyön keresztül a Hegyhátig és Kemenesaljáig. Személyes interjúk és kérdöivek készülttek valamennyi polgármesterrel, valamint az egyéni vállalkozók kivételével valamennyi gazdasági szervezettel.

A vizsgálat eredményei a kedvezỏtlen adottságok feltárásában az alábbiakban összegezhetök (Rechnitzer 1991):

- gyenge mezögazdasági adottságok;

- jelentéktelen ipari, termelöi bázisok, kevés gazdasági szereplö;

- aprófalvas és funkcióhiányos településhálózat;

- csökkenő és aktivitását jelentősen vesztỏ népesség;

- centrumok hiánya, gyenge elérhetősége;

- minimális interregionális kapcsolatok, az azokat lehetővé tevő infrastruktúra kiépületlensége.

A mikrotérségek megújitásánál számba vehető erőforrások:

- kedvezö természeti és települési környezet;

- emberi kapcsolatokban gazdag, nyitott lokális közösségek;

- bizonyos termelési-tevékenységi kultúrák megmaradása;

- egyes települések meginduló rehabilitációja;

- a nyitottá váló határok következtében erösödő tranzit idegenforgalom serkentő hatásai.

A VETÖSZ szerepét a területfejlesztési törvény hatályba lépését követően (1996) a KSH kistérségenként megalakult önkormányzati térségfejlesztési társulások vették át. A REGINNOV több ágazatot (gazdaság, humán eröforrás, környezet stb.) átfogó tevékenysége napjainkra letisztult, döntően humáneröforrás-fejlesztéssel tanulmányok, koncepciók, képzési programok készítése és lebonyolítása foglalkozik. Az elmúlt évtized során szoros munkakapcsolat alakult ki az Iroda és a NYUTI 1993-2000 között szombathelyen müködö Vas Megyei Kutatócsoportjấval.

A bemutatott példák kétféle modellt követtek. Az egyik modellben a vizsgált térség, témakör alapos feltárásának bázisán a kutatók a (politikai) döntéshozók számára fogalmaztak meg javaslatokat az adott térség, témakör fejlesztése érdekében. A másik modell egy decentralizált területfejlesztési intézmény létrehozásának és müködésének feltételeit alapozta meg. A kutatási metodika is két irány követett. Az átfogó térségi vizsgálatok empirikus anyagát az adott terület személyes bejárása során készített interjúk és személyesen lekérdezett kérdőivek adták. A határ menti kutatásban pedig a kulcsszereplökkel készített interjúk, az önkitöltéssel készült kérdöívek és a közös kutatási workshopok biztosították a kutatás információs bázisát. 
Ennek a szakasznak az összegzéseként megállapítható, hogy a fenti munkák az új típusú kutatásfinanszirozáson túl biztosították, hogy a NYUTI kutatások az ÉszakDunántúl alapos ismeretére, kiterjedt saját empirikus vizsgálatokra támaszkodhattak. Ez emelte az intézet reputációját mind a térségben, mind nemzeti szinten. Ugyanakkor hozzájárult az egyes kutatók tudományos ambícióinak kiteljesítéséhez is, hiszen az egyes kutatások lehetôséget biztosítottak arra, hogy a mérsékelt költségvetésü kutatási alapok megalapozó, elméleti jellegủ munkáit gazdag empirikus vizsgálatok támogassák.

\section{A stratégiai szemlélet megjelenése a területfejlesztési tervekben}

Ez a fejezet a tervezési rendszer megújitásának az EU csatlakozásból és a Maastricht-i szerződésböl fakadó követelményekböl, a stratégiai tervezés módszerének hazai megalapozásából indul ki. Ez a szemlélet először a kilencvenes évek első harmadában az $I$. Phare Területfejlesztési Program keretében, EU szakértők közremüködésével kistérségi (10 kiválasztott térségfejlesztési szövetség) és megyei koncepciók (Szabolcs-Szatmár-Bereg) készítésénél érvényesültt ${ }^{4}$.

A kísérleti program célterületei a kistérségek és a megyék voltak. Ugyanakkor éppen Maastricht hatásaként vârható volt a megyéknél nagyobb területi egységek, a fejlesztési-statisztikai régiók elötérbe kerülése. Az 1994-1999-es EU tervidőszakban jelentősen növekedett a Strukturális Alapokból biztosított források nagysága (2. táblázat), melynek célterülete, elosztási bázisa a NUTS 2 szint. A források felhasználásának alapja az érintett régiókban elkészített területfejlesztési stratégia volt. Ez arra ösztönözte a kormányzatot, hogy meghatározott mintarégiókra kezdje meg területfejlesztési koncepciók készítését. A KTM megbízásából 1993-ban az RKK Alföldi Tudományos Intézete (ATI); egy négy megye és magánszemélyek által létrehozott fejlesztési alapitvány kezdeményezésére 1992 és 1996 között Dél-Dunántúlra az RKK Dunántúli Tudományos Intézete (DTI) készített fejlesztési koncepciót (Hrubi 1997b).

Az 1995. év elején a KTM felkérte a NYUTI-t egy, az uniós szemléletben készülö minta regionális területfejlesztési koncepció vázlatának kidolgozására. Ehhez háttérként egy ábrát adott át a megbízottnak, amely az .EU területfejlesztési tervezésének sémáját tartalmazta. Ennek lényege az volt, hogy a tervezést egy folyamatnak tekintette, amely egy adott térség társadalmi-gazdasági-környezeti helyzetének feltárásával indult, és ugyanezen tényezökben bekövetkezett változások monitoringjával zárult. Tehát a visszajelzés egyúttal indítja az új tervezési ciklust.

Ennek hátterében az EU költségvetési és ezen belül az EU területfejlesztési politikájának megvalósítását segîtő Strukturális Alapok tervezési ciklusai állnak. Ennek idötávja ciklusról ciklusra változik, de jellemzöen egy nemzeti szintủ választási ciklusnál (általában $4 \mathrm{ev}$ ) hosszabb, de két ciklusnál rövidebb időszakot fog ât ${ }^{5}$. Ennek célja az, hogy a hosszú távra, konszenzus alapján megfogalmazott célok megvalósitását ne befolyásolják a választásonként előfordulható politikai kurzusváltások. 
A két értékelés közötti időszakban elöször az adott térség jövőképét és hosszú távú (10-15 év) célkitúzéseit megfogalmazó koncepció, stratégia készül el. Ennek bázisán a folyamat kettéválik, és a tervezés folytatódik egyfelöl a stratégia meghatározott tervidőszakra szóló programozásával (területfejlesztési program készítése), másfelöl a megvalósulás keretfeltételeit biztosító szabályozás kialakításával (terủletrendezési terv készítése). A NYUTI a területfejlesztési koncepció metodikájának kidolgozására, majd a koncepció elkészítésére kapott megbízást.

\section{TÁBLẢZAT}

A Strukturális Alapok célja és forrásai 1989-2006 (milliárd euró)

(Objectives and Distribution of Structural Funds and Community Initiatives 1989-2006 (billion Euro)

\begin{tabular}{|c|c|c|c|}
\hline Cél & $1989-1993$ & $1994-1999$ & $2000-2006$ \\
\hline $\begin{array}{l}\text { 1. célterület: Az elmaradott régiók fejlődésének } \\
\text { elösegítése }\end{array}$ & 37,0 & 94,0 & 135,9 \\
\hline $\begin{array}{l}\text { 2. célterület: Az ipar hanyatlásával súlyosan érintett } \\
\text { régiók átalakítása }\end{array}$ & 6,4 & 15,3 & 22,5 \\
\hline $\begin{array}{l}\text { 3. célterület: A tartós munkanélkuuliség leküzdése, a } \\
\text { fiatalok munkába állásának segítése }\end{array}$ & 7,2 & 15,2 & 24,1 \\
\hline $\begin{array}{l}\text { 4. célterület: A foglalkoztatottak alkalmazkodá- } \\
\text { sának megkönnyítése az új termelési rendszerekhez }\end{array}$ & & & - \\
\hline $\begin{array}{l}\text { 5a. célterület: a mezógazdaság szerkezeti } \\
\text { átalakításának segítése }\end{array}$ & 3,3 & 6,1 & - \\
\hline $\begin{array}{l}\text { 5b. célterület: a mezőgazdasági területek } \\
\text { fejlödésének elősegitése }\end{array}$ & 2,7 & 6,9 & - \\
\hline $\begin{array}{l}\text { 6. célterület: a rendkívül alacsony népsürüségü } \\
\text { régiók segítése }\end{array}$ & - & 0,7 & - \\
\hline Strukturälis Alapok összesen & 56,6 & 138,2 & 182,5 \\
\hline Kohéziós Alap (1994-töl) & - & 15,1 & 18,2 \\
\hline $\begin{array}{l}\text { PESCA (1994-1999)/Speciális halászati támogatás } \\
\text { (2000-tôl) }\end{array}$ & - & 0,3 & 1,1 \\
\hline Innovatív intézkedések támogatása & - & 0,4 & 1,0 \\
\hline LEADER program (1991-tól) & 0,4 & 1,4 & 2,0 \\
\hline INTERREG program (1990-től) & 0,9 & 2,9 & 4,9 \\
\hline $\begin{array}{l}\text { EMPLOYMENT+ADAPT (1990-1999)/EQUAL } \\
\text { program (2000-töl) }\end{array}$ & 0,5 & 2,8 & 2,8 \\
\hline URBAN program (1994-tỏl) & - & 0,8 & 0,7 \\
\hline Más Kozơsségi Kezdeményezések együtt & 4,6 & 5,2 & - \\
\hline Közösségi kezdeményezések összesen & 6,4 & 13.1 & 10,4 \\
\hline Összes strukturális beavatkozást segitõ támogatás & 63,0 & 167,1 & 213,2 \\
\hline
\end{tabular}

1989-1993: Strukturális Alapok 1998. évi áron, Közossségi kezdeményezések 1993. évi áron;

1994-1999: 1994. évi áron;

2000-2006: 1999. évi áron.

Megjegyzések: A 2000-2006-os idószakban a célterületek száma a korábbi ơtröl háromra csőkkent:

1. célterület: Az elmaradott régiók fejlesztésének elösegitése

2. célterulet: A hanyatló ipari, rurális, halászati és problémás városi térségek támogatása

3. célterullet: A korszerỉ oktatási, képzési és foglalkoztatási rendszerek adaptálása, aktív foglalkoztatáspolitika A PESCA halászati támogatás 1994-1999 kőzőtt mükődő kőzösségi kezdeményezés volt, azok a régiók kaphatják, amelyek nem tartoznak az 1. célteruletbe.

Forrás: Forman (2000) 145-146. o. és Horváth (1998) 347. o. alapján saját szerkesztés. 
A kijelölt terület is speciális volt, hiszen Északnyugat-Dunántúl néven GyörMoson-Sopron, Vas, Veszprém és Zala megyéket foglalta magában. Ennek a területi összetételnek volt egy olyan motivációja, hogy az 1995-1999 közötti idószak magyar-osztrák PHARE CBC megyéi közé bevonva Veszprém megyét, esetleg ez a megye is, mint egy NUTS 2 szintű régió része, kedvezményezettjévé válhat ennek a Közösségi Kezdeményezésnek.

Az 1995 februárjában Györben a Megyeházán bemutatott és az érintett minisztérium és megyék szakembereivel megvitatott koncepció-vázlat integrálta az EU-s tervezési folyamatábra, az RKK által addig készített két regionális fejlesztési koncepció, a PHARE Területfejlesztési Mintaprogram keretében, EU-s szakértök segítségével készült Szabolcs-Szatmár-Bereg megyei területfejlesztési koncepció, valamint a több évtizedes múltra visszatekintő vállalati stratégiai tervezés elemeit.

Ez a vázlat azonban számos új elemet is tartalmazott (1. ábra):

- Pontosan definiálta a helyzetfeltáró szakasz vizsgálati területeit, gondosan szétválasztva a külsö és a belsö környezet értékelését.

- A külsö környezet elemzésében a versenyképesség vizsgálatára helyezte a hangsúlyt. Erre ơnálló metodikát fejlesztett ki (2. ábra). A külsö környezet értékelése több rétegủ volt: Elöször összevetette a megye föbb társadalmigazdasági mutatóit az EU átlaggal, majd elhelyezte a megyét az országos folyamatokban.

- A belső adottságok vizsgálatánál a hagyományos ágazati elemeket - humán erőforrások, gazdasági bázis, infrastruktúra és a kilencvenes évek első felétöl a környezet - kiegészítették a NYUTI innovációs kutatásainak új elemei, az évtized elején elindult olyan társadalmi innovációk bemutatása, mint a civil társadalom kezdeményezései vagy a kistérségi fejlesztési szövetségek.

- Már a koncepció megvalósithatóságára is gondolva elemzés készült a területfejlesztési szereplök eröforrás kapacitásairól.

- A helyzetelemzést összegzö SWOT analizist nem követte azonnal a jövőkép és a koncepció kifejtése, hanem a nemzetközi regionális kutatási irodalomban a kilencvenes évek első felétől terjedó ún. forgatókönyv elemzési technika alkalmazásával ${ }^{6}$ különböző fejlödési utakat vázoltak a tervezők.

- Maga a koncepció nem csupán a fejlesztési akciók ágazati gyüjteményeként jelent meg, hanem egy többszintú rendszert alkalmazott (Lados-Rechnitzer 1997a):

- Az előző munkafázisokra támaszkodva megfogalmazta az adott térség jövóképét, majd a jövőkép megvalósítását segitő prioritásokat és intézkedéseket.

- Az intézkedéseket, elsösorban a Szabolcs-Szatmár-Bereg megyei koncepcióban alkalmazott módszert adaptálva és továbbfejlesztve, szinte programozási szintig elókészitve fogalmazta meg: a probléma és a szükségletek bemutatásától, az intézkedés leírásán keresztül a megvalósítás javasolt menedzsment-szervezetének, lehetséges forrásainak és a kapcsolódó tervezési munkák meghatározásáig. 


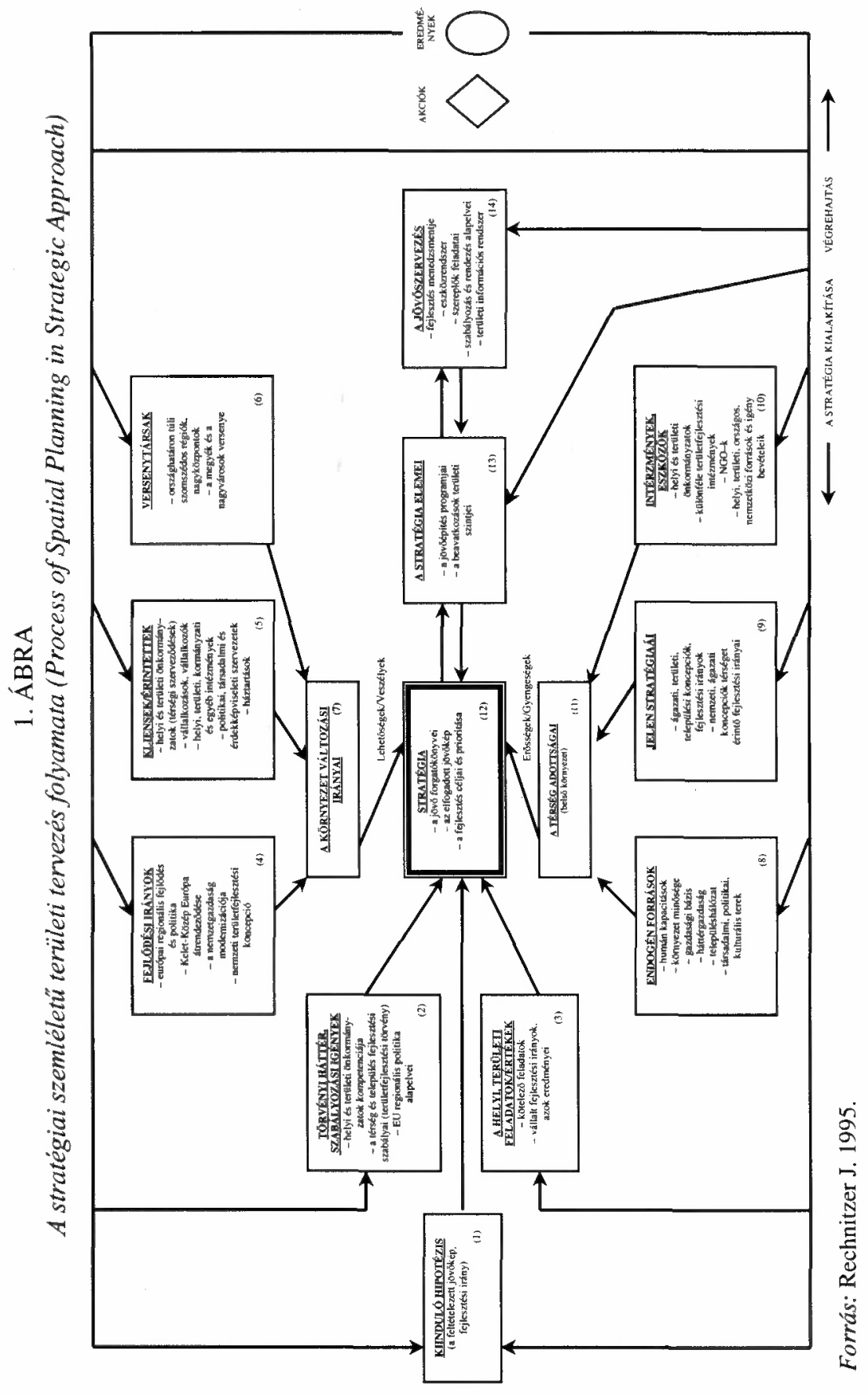




\section{2. ÁBRA}

A regionális versenyképesség tényezöi

(The Factors of Regional Competitiveness)

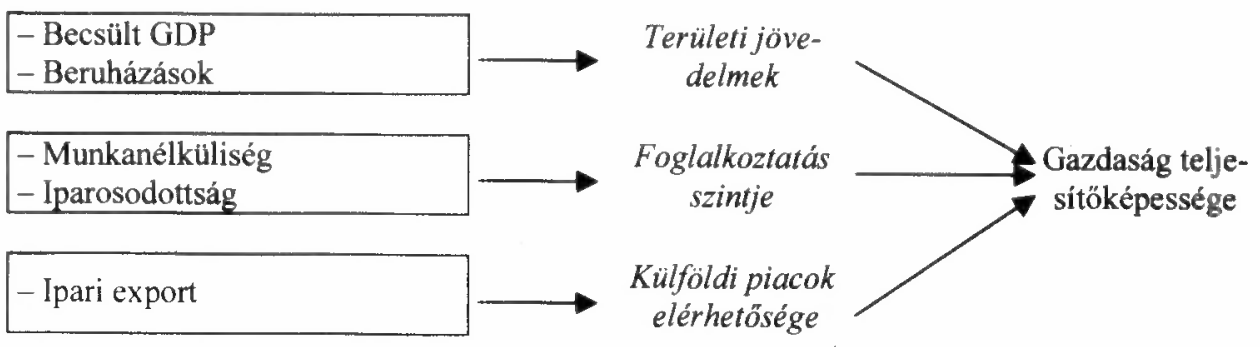

\begin{tabular}{|l|}
\hline - A szolgáltató szektorban \\
foglalkoztatottak száma \\
- A fejlett üzleti szolgáltató \\
szek-torban foglalkoztatottak \\
száma \\
- A bankrendszer \\
\hline
\end{tabular}

- Vállalkozások terjedése - Külfơldi tőke

- A felsőoktatásban részt vevő hallgatók száma

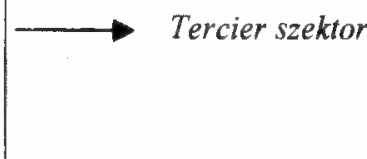

Vállalkozás és tỏkeaktivitás

Képzettség

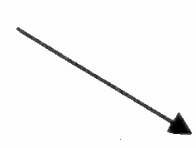

Fejlesztési adottságok

\section{- Népesség száma \\ - Vándorlások \\ - Nyugdíjasok száma \\ - Egeszségügyi szolgáltatások sürüsége}

\section{- Lakásépítés}

- Budapest elérhetősége - Telefonellátottság

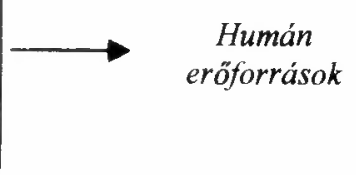

Háztartások aktivitása

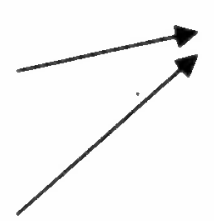

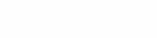

Forrás: Rechnitzer (1995). 
- Az egyes intézkedéseket a térség differenciált területi sajátosságaiból fakadóan kistérségi szinten csoportosított beavatkozási területekhez kötötte. A koncepció tudatosan vállalta, hogy az innováció-orientált és az endogén erőforrásokra támaszkodó terủletfejlesztési politikára építi a térség fejlesztési stratégiáját.

- Tudatosítva azt, hogy egyes akciók csak nemzeti szinten kezelhetök, a koncepció külön foglalkozott az országos kompetenciába tartozó, a térség számára kiemelkedö fontosságú projekt szintủ javaslatokkal.

- A koncepció jelezte a megvalósítás lehetséges kereteit, kitért a monitoring szerepére és tartalmára.

A progresszív metodika nem csupán a kezdeményezö KTM, de a folyamatba bevont megyék tetszését is elnyerte. Így a KTM mintarégiós koncepció megfogalmazására vonatkozó megbízása mellé csatlakozott Györ-Moson-Sopron, Vas és Veszprém megye önkormányzata is saját megyéik fejlesztési koncepciójának elkészíttetésével ${ }^{7}$. A kibövülő források, a párhuzamosan folyó tervezés tette lehetővé, hogy az egyes koncepciók széles szakértöi kör bevonásával és többszintü empirikus felmérésekkel megalapozottan, ugyanakkor egységes metodika szerint készưljenek. Ez biztosította a mintarégió és a megyék koncepcióinak az összhangját, kohézióját is.

\section{A megyei koncepciók készítésének sajátosságai}

Tartalmilag a mintarégiós koncepció a legizgalmasabb, amelynek fóbb háttértanulmányait és a stratégia egészét a Tér és Társadalom (TÉT) 1997/1. száma mint tematikus kötet tartalmazza és teszi hozzáférhetővé a szakmai közönség és más érdeklödők számára. A koncepció készítésének folyamatát tekintve azonban az egyes megyei koncepciók összevetése mutat számos érdekességet és tanulságot. Ebbe az értékelésbe a fenti összetett tervezési programon túl számba vesszük a Fejér megye hosszú távú területfejlesztési koncepcióját is, amely már a korábban indított megyei koncepciók készítésének tapasztalatait is figyelembe vette (3. táblázat).

A mintarégió megyéiben egységesen 1995 májusában kezdödött meg a munka. A befejezés azonban rendkívül eltérö volt. Györ-Moson-Sopron megyében 1996 júniusában még a megbízó megyei önkormányzat fogadta el a koncepciót, amelyet a következó hónapban ,apportált" a frissen megalakult megyei területfejlesztési tanácsba. Így az MTT 1996. évi elsö pályázati kiírásánál már a koncepciót tekintették a pályázati elbírálás iránytújének ${ }^{8}$.

Veszprém megyében 3, Vas megyében 4 éves átfutással nyert elfogadást a koncepció. Veszprém megyében az elhúzódás oka a menet közben megalakult MTT, majd a kötelező egyeztetési eljárásról szóló miniszteri rendelet volt ${ }^{9}$. Bár a megyei önkormányzat volt a megrendelö, az időközben hatályba lépett területfejlesztési törvény a területfejlesztési koncepciók készítésének feladatát az MTT-k hatáskörébe utalta. Így az a furcsa helyzet fordult elö, hogy a koncepció készítését a megyei önkormányzat finanszírozta, de az elfogadásról a végső szót az MTT mondta ki. 


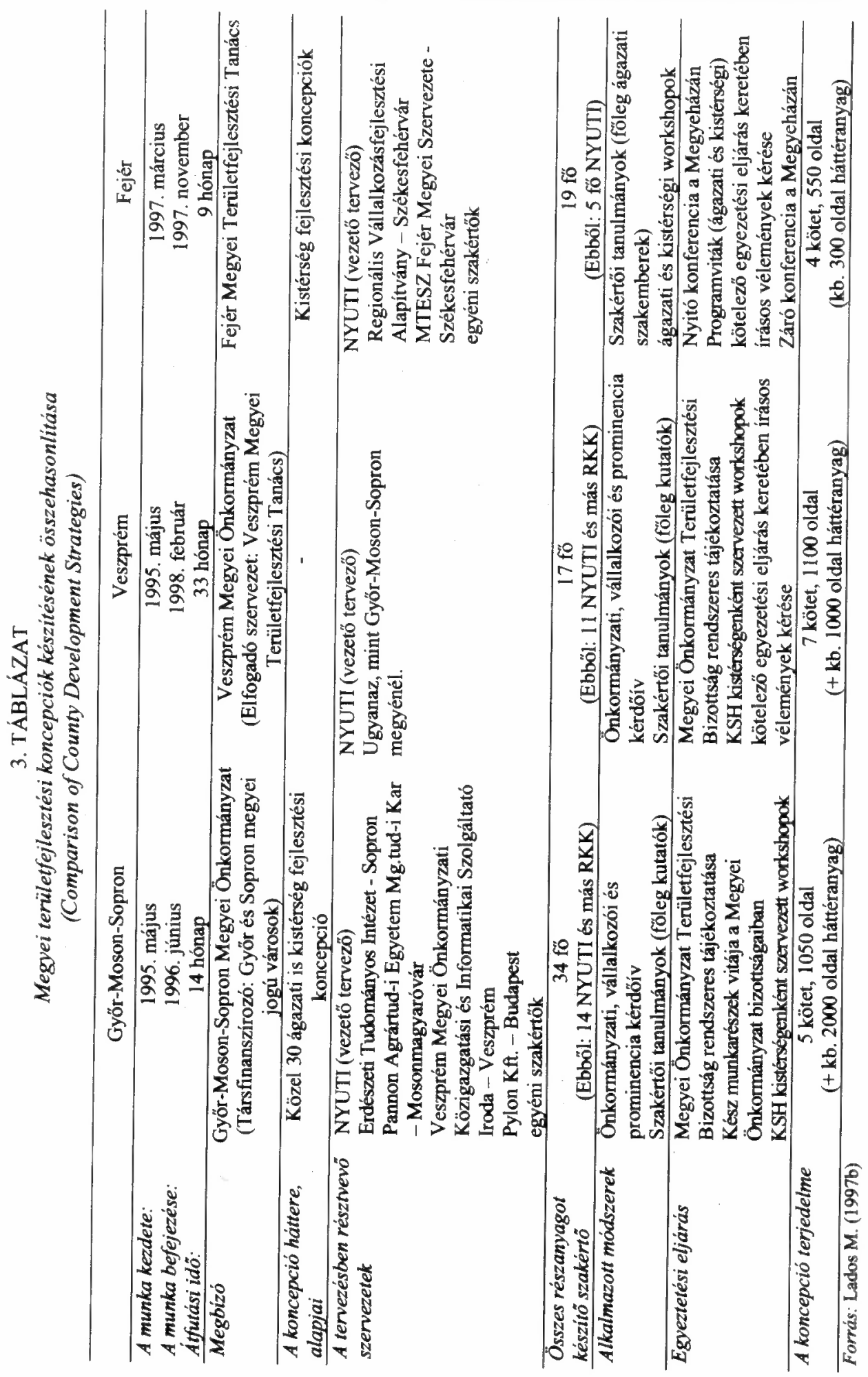


1996 őszén az MTT plusz feladatokat határozott meg - kistérségi és ágazati egyeztetések - a tervezők számára. 1996 decemberében elfogadást nyert a koncepciók kötelező egyeztetési eljárásának szabályozása, így a folyamatban lévő koncepciót a megbízók ennek a rendszernek is megfeleltették. Így 1997 öszére alakult ki a koncepció azon változata, amelyet 1998. januárban a megyei önkormányzat, majd februárban az MTT is elfogadott.

Vas megyében a csúszást más tényező okozta. Ott a megyei önkormányzat elnöke (aki a törvény szerint egyben az MTT elnökévé is vált) javaslatára átmenetileg leállították a tervezési munkát. Álláspontja szerint a megyei koncepciónak alulról kell építkeznie, s ez véleménye szerint csak akkor megvalósítható, ha elöször elkészül a megye valamennyi kistérség fejlesztési társulásának fejlesztési koncepciója.

Az álláspont azért nehezen elfogadható, mert a megyei koncepció nem egyszerüen a kistérségi koncepciók összefésülése. Vannak országosan, regionálisan, megyei, kistérségi és helyi szinten megoldható feladatok. Ezért a megyei szinten vannak sajátosan megjelenő fejlesztési igények is. Másoldalról a megyei programot a megye települési önkormányzatainak teljes körủ megkérdezése alapozta meg, tehát szándékaik, elvárásaik beépültek a formálódó koncepcióba. Harmadrészt a koncepció időszakonkénti monitoringja biztositja, hogy az idöközben elkészültt ágazati és területi tervek beépüljenek a koncepcióba.

Fejér megyében, a már meglévő tapasztalatok bázisán és a jó előkészítettség miatt a koncepció készités-elfogadás átfutási ideje mindössze háromnegyed év volt. Fejér megye esetében a megbizó már az indulásnál is az MTT volt.

Nem mindegy, hogy milyen alapokkal indul egy átfogó koncepció készitése. Györ-Moson-Sopron megye esetében gazdag háttéranyag állt a tervezök rendelkezésére. A megyei önkormányzat önként vállalt feladatként megtartotta a volt megyei tanácsi tervosztály egy kis szeletét, és tudatosan ágazati és kistérségi koncepciók készíttetésével készült a jövö területfejlesztési feladatainak megalapozására.

$\mathrm{Az}$ ellenkező példát Veszprém megye szolgáltatta, ahol az önkormányzati rendszerre való áttérés kezdetétől napjainkig a megyei önkormányzat a megyerendszer fenntartásának élharcos szerepét vállalta, szervezve a Megyei Önkormányzatok Szövetségének (MÖSZ) munkáját és a MÖSZ folyóiratának, a Comitatusnak a megjelenését. Ugyanakkor a megye megbízásából nem készült egyetlen ágazati vagy kistérségi koncepció sem 1990 és 1996 között. Fejér megyében a székesfehérvári Regionális Vállalkozásfejlesztési Alapitvány (RVA) által készített kistérség fejlesztési koncepciók jelentettek biztos alapot a koncepció készítéséhez.

A mintarégiós programmal együtt készülö megyei koncepciók esetében a NYUTI egy széles szakértöi stábbal dolgozott, amelyben a NYUTI és a partnerszervezetek között közvetlen és rendszeres volt a kapcsolat. Fejér megyében csupán két szervezettel állt a vezető tervező kapcsolatban (RVA, MTESZ Fejér Megyei Szervezete), és ezek a partnerszervezetek biztositották további megyei szakértó 
szervezetek és személyek bevonását a folyamatba. A korábban kialakult helyi kapcsolatrendszereknek köszönhetően ez egy jól müködö hálónak bizonyult a tervezés során, és a koncepció megyei fogadtatását is nagymértékben segítette ${ }^{10}$. A kétféle munkaszervezés a tervezésben résztvevök összetételére is hatással volt. Míg a mintarégiós koncepció körébe tartozó tervezési munkáknál nagyjából a stáb felét a NYUTI és az RKK kutatói adták, addig a Fejér megyei koncepció esetében ez az arány a résztvevők egynegyedére csökkent.

A stratégiai tervezés a szereplökre épít, azok jövöképét kíséreli meg összekovácsolni. Ez egy folyamatos kapcsolatrendszert, részvételt, együttdolgozást kíván meg a tervezöktől a területrendszer elemeivel és a szereplőivel. Az elméleti modellel nincsen baj, a tervezésbe a szereplök minél szélesebb körét be kell vonni. A baj ott kezdődik, hogy kik legyenek a tényleges partnerek, kik jelenítik meg a területrendszer alkotóit, annak egyes alrendszereit, milyen mértékủ képviseletet, „beleszólást” kapjanak a terv kidolgozásához, és persze megvalósításába. A lehetséges szereplök az önkormányzatok és intézményeik, az ágazati dekoncentrált szervezetek, a gazdaság, a nonprofit szféra és a lakosság. Kutatási tapasztalataink azt mutatják, hogy a területi szintek növekedésével a bevonható szereplök száma csökken, azok egyre áttételesebb intézményrendszerekben jelennek meg. Így a vélemények és akaratok érvényesítési terei a nagyobb területi egységek tervezése során mérséklödnek (Rechnitzer 1998).

Módszertanilag is érzékelhető egy váltás a korai és későbbi koncepciók készítése között. A korábbiak esetében a helyzetfeltáró szakértői tanulmányokat a kutatók készítették, valamint teljes körú önkormányzati, mintavételen alapuló vállalkozási, valamint ún. prominencia kérdőívek ${ }^{11}$ tesztelték az adott megye területfejlesztési elképzeléseit. A kérdỏívek azonban elsősorban nem a szabadon futó ötleteket gyüjtötték össze, hanem a kutatók által javasolt fejlesztési listákat rangsoroltatták a megkérdezettekkel. Fejér megyében - elsősorban az ágazati - szakértői tanulmányokat megyei ágazati szakemberek készítették. A fejlesztési javaslatokat pedig ágazati és kistérségi workshopok keretében gyűjtötték össze a tervezők, amiket az erős megyén belüli kapcsolatrendszerrel bíró RVA szervezett.

A kezdeti koncepciók munkafolyamatában a prekoncepció elkészítése volt az a munkafázis, amely szélesebb körủ egyeztetésen ment keresztül. Míg a korábbi munkarészeket csak az adott megye Területfejlesztési Bizottsága tárgyalta, addig a Prekoncepciót, amely magában foglalta a megye jövőszervezésének lehetséges forgatókönyveit is, már valamennyi bizottság, az önkormányzat közgyülése, valamint KSH kistérségenként szervezett workshopok is megvitatták. Ennek a munkafázisnak az volt a szerepe, hogy a felvázolt jövőképek közül válasszon a megye, majd a tervezők a választott forgatókönyv mentén dolgozták ki a koncepciót.

A Györ-Moson-Sopron megyében még tisztán múködő modellt Veszprém megyében megzavarta, hogy az első munkaszakaszok időbeli eltolódásával az MTT is belefolyt a tervezési folyamat felïgyeletébe. Ennek hatására a kistérségeken kívül, egy-egy workshop keretében a gazdasági kamarák és a megyei MTESZ 
közremüködésével a különböző ágazati szereplök is megvitatták a Prekoncepcióig elkészült munkarészeket.

$\mathrm{Az}$ időkőzben hatályba lépett kötelező egyeztetési eljárás miatt a megszólítottak köre még jobban kitágult. Annak során ugyanis a minisztériumoktól, az ágazati DEKO-któl, valamint a megye valamennyi települési önkormányzatától, söt a szomszédos megyék MTT-itöl is írásos véleményt kellett kérni. Erre a megszólított szervezeteknek 60 nap állt rendelkezésére. A beérkezett véleményekröl összegzést kellett készíteni és megválaszolni, hogy az adott észrevétel beépült-e a koncepcióba. Ha nem, akkor indokolni kellet, hogy miért nem. Ebben a tanulási időszakban az észrevételt beküldők általában magukat keresték a koncepcióban és jelezték, hogy hol, milyen súllyal kellene szerepelniük ${ }^{12}$. Általában az ágazati minisztériumok és DEKO-k többsége megküldte a véleményét, míg az önkormányzatok többségét mérsékelt aktivitás jellemezte.

Érdekes megemlíteni, hogy mekkora írott anyag keletkezett az egyes koncepciók készítésekor. A Györ-Moson-Sopron megyei stratégia egyes munkafảzisaiban elkészült kötetek összesen több mint ezer oldalt tartalmaztak, amelyet további mintegy 2000 oldalnyi háttértanulmány támogatott. Ezt a hatalmas mennyiségü anyagot minden bizonnyal összesen két ember - egyrészt a kötetek szerkesztöje, másrészt a megbizó képviselöje - olvasta el a megyében. Veszprém megyében hasonló volt a helyzet, igaz ott az elhúzódó tervezési folyamat miatt a koncepciónak a végleges változat előtt három munkaanyaga készült egyenként nagyjából 80-100 oldal terjedelemben, valamint a háttértanulmányok összes terjedelme is nagyjából a Györ-Moson-Sopron megyei fele volt.

Fejér megyében egyértelmü törekvés volt a tervezési dokumentum teljes terjedelmének rövidítésére a széles körben való megismertetés érdekében. Ezt elsősorban a háttértanulmányok terjedelmének limitálásával igyekeztek megvalósítani a tervezök, de még így is a koncepció négy kötete összesen meghaladta az 500 oldalt. A később készülő koncepcióknál már belépett a rövid összefoglalók készítésének igénye. Így a döntéshozók általában már csak azt kapták meg közvetlenül, de a megbízónál több példányban meglévő teljes dokumentumot is elkérhették, ha egészében kívánták látni a koncepciót a felmérésektöl a stratégia meghatározásáig.

Összegzésként megállapitható, hogy ez az idöszak egyértelmüen jelzi a NYUTI úttörö szerepét, hiszen az északnyugat-dunántúli minta stratégia készítéséhez kialakított módszertan épült be a területfejlesztési koncepciók készítésének nemzeti szintủ szabályozásába ${ }^{13}$. Ugyanakkor a stratégia készítés háttere az egyes térségeket tekintve rendkivuuli módon különbözött, és maga a módszertan is egy folyamatos fejlödési pályát irt le. A tapasztalatok összegzése két szinten is megtörtént erre a periódusra. Egyfelől az Északnyugat-Dunántúl területfejlesztési stratégiája a szakmai közönség számára hozzáférhetővé vált a TÉT speciális számaként (1997/1), másfelöl a NYUTI országos konferenciát rendezett a területfejlesztési koncepciók - nemzeti, regionális, megyei, kistérségi és település szintű készítésének tapasztalatairól (Györ, 1997. április 3-4.). A konferencián 
elhangzottakat az egyes szekciók vezetöi összegezték a TÉT 1997/3. számában (Hrubi 1997a; Szörényiné 1997b).

\section{Tervezési konzorciumok: szükség vagy kényszer?}

Az EU támogatáspolitikájában kiemelt szerepe van a partnerségnek. Ezt igyekszik érvényesíteni mind a beruházási, mind a tervezési-kutatási jellegü tevékenységeknél. Ez utóbbi esetben, különösen a több országot átfogó projektek esetében jellemző, hogy tervezói-kutatói konzorciumok valósítják meg a projektet. A dolog lényege az, hogy egy adott szervezet nem képes egy komplex feladat valamennyi részterületének megoldására. Különösen igaz ez a területfejlesztésre, amely horizontális módon számos ágazatra fejti ki hatását. Így többféle szakmai háttérrel rendelkező szakértő bevonása szükséges a projekt megvalósításába.

Nemzetközi projektek esetén a témába bevont országok, régiók legjobb ismerői az adott területen tevékenykedő hazai szervezetek. Ezért az EU Közbeszerzési Értesítőben közzétett projektfelhívásokat követően megsokszorozódik a konzorciumépító, partnerkereső levél, telefon, fax és e-mail forgalom Európában. A konzorciumba való bekerülés alapfeltétele, hogy a pályázó szervezet - valamely tématerületen - Brüsszelben regisztrált szakértői szervezet legyen ${ }^{14}$. Az utóbbi években a hazai pályáztatási gyakorlatban is elterjedtté vált, hogy adott feladat elvégzésére elsősorban konzorciumok pályázatát fogadjåk be. A kilencvenes évek közepétől a NYUTI számos nemzetközi és hazai megkeresést kapott tervezői konzorciumokban való közremüködésre.

A konzorcium többnyire jó megoldás a sokféle szakértelmet, illetve területi ismeretet igénylő feladatoknál. Számos esetben azonban inkább kényszernek érzik a résztvevök ennek a formának az alkalmazását. Az alábbiakban a konzorciumban történő tervezés három megközelítését tárgyaljuk a NYUTI példáján:

- hazai feladatok hazai partnerekkel;

- külföldi szakértők által vezetett hazai projektek;

- transznacionális projektek nemzetközi stábbal.

\section{Hazai konzorciumok - hazai projektek}

A területfejlesztési törvény hatályba lépését követően sorra alakultak a megyék önkéntes szerveződésével a regionális fejlesztési tanácsok ${ }^{15}$. Ez 1998-ig az ország teljes lefedettségével megvalósult. Néhány megye (pl. Zala, Pest) és Budapest a törvény specialitásai miatt több régiónak is tagjává vált. Mivel a törvény a regionális tanácsok egyik fö feladataként a régió fejlesztési dokumentumainak elkészítését jelölte meg, több régió is megkezdte hosszú távú fejlesztési stratégiájának kidolgozását. A NYUTI fö vizsgálati területét érintően a NyugatDunántúl PHARE CBC, míg a Balaton és a Közép-Dunántúl a központi TFC forrásaira támaszkodva hirdette meg tervezési pályázati felhívását. 
A Nyugat-Dunántúlon a megrendelö az FVM Phare Programirányító Iroda volt. A projekt megvalósítóját meghivásos pályázat keretében választották ki. A megbízást a Pylon Kft. vezette konzorcium nyerte el, amely döntően budapesti székhelyủ szervezeteket tömörített. A munkába helyi szakértöket is bevontak. A tervezés közvetlen felügyeletét, a tervezőkkel történő kapcsolattartást, a régiót alkotó megyék által delegált területfejlesztési szakemberek látták el. Ez lényegében a PHARE projektek esetében megkövetelt „Steering Committe" (Irányító Bizottság) vagy „Steering Group” (Irányító Csoport) létrehozását és működtetését jelentette.

A hazai finanszírozású projektek esetében nyílt pályázati felhivást tett közzé az érintett RFT. Egyfajta társfinanszírozási elv érvényesítése érdekében azonban a pályázónak a teljes tervezési költség egy meghatározott hányadát saját forrásból kellett vállalnia. A 30-40 MFt értéküre becsült munkák sajăt forrás igénye egy NYUTI jellegủ, költségvetési pénzekre támaszkodó szervezet számára szinte elérhetetlenné tette pályázat közvetlen benyújtását. Mindkét jelzett régió esetében a NYUTI által elkészített tematikával pályázott és nyert a Balatoni (BRFT), illetve a Közép-dunántúli Regionális Fejlesztési Rt. (KDRFT). A tervezési munka közvetlen felügyeletét az Országos Területfejlesztési Központ (OTK) régió igazgatója látta el.

A nyertes szervezetek a munkát - az OTK ösztönzésére - a koncepció vázlat egyes munkarészeire kiírt meghívásos pályázatok alapján létrejött konzorciummal kívánták megvalósítani. Ez a modell tisztán a Balaton koncepció esetében érvényesült. A NYUTI a helyzetfeltáró munkarészek és a koncepció elkészítésére kapott megbízást. A munka minőségbiztosítását, az egyes munkarészek szerkesztését tekintve a NYUTI vezetỏ tervezỏi feladatokat is ellátott. A többi munkarészt (pl. a koncepció megvalósításának szervezeti rendszere, finanszírozása, marketing koncepciója) más, a pályázatok alapján kivaalasztott szervezetek végezték el.

Ugyanakkor a korábbi tervezési projektekhez képest alapjaiban eltért a NYUTI pozíciója. Mind befelé, mind kifelé a BRFT jelent meg a projekt vezetójeként:

- ellátta a projekt, illetve az egyes munkacsapatok közötti koordinációt;

- létrehozta és müködtette a neves, nemzetközi és EU tapasztalatokkal rendelkező szakembereket magában foglaló Tanácsadó Testületet;

- szervezte és vezette a térségi szereplők tervezési folyamatba történő bevonását segítỏ workshopokat;

- sajtótájékoztatókat szervezett, és tartotta a médiákkal a kapcsolatot;

- biztosította az OTK felé szükséges információk átadását, illetve a Magyar Államkincstárral (Kincstár) kapcsolatos feladatok (finanszírozási szerzỏdés) ellátását.

A KDRFT a Közép-dunántúli koncepció megvalósításában sokkal inkább a közepes nagyságú PHARE CBC projekteknél alkalmazott „Framework Contractor" (Keretszerződő Szervezet) szerepet látott el. Nem törekedett a projekt szakmai vezetésére, hanem kiválasztotta a tervet elkészítő csapatot és elvégezte a projekt adminisztrációjával kapcsolatos szerződési (Kincstár) és jelentési (OTK) teendőket. Klasszikusan a Keretszerződő Szervezet csak a vezető tervezőt választja 
ki; míg a stábot a vezető tervezỏ alakítja ki. Ez biztosítja, hogy egymással együttmüködésre képes szervezetek végzik el a feladatot. A közvetlen felkérések következtében a tervezöi konzorcium nagyjából ugyanazon szereplökböl állt, kiegészülve a Fejér megyei koncepció készítésénél is közremüködỏ szervezetekkel.

A NYUTI ezúttal is egyes fejezetrészek elkészítésére, és a vezető tervezői feladatok ellátására kapott megbízást. A balatoni munkához képest azonban ez esetben az együttmúködés keretein belül, szakmailag a NYUTI volt a projekt felelöse. A balatoni tapasztalatok birtokában kicsit gördülékenyebb volt már a kényszer társulás müködése is. Ezt a tervezés folyamatába beépített két kétnapos tervezöi workshop is segítette. A tervezési idöszakban megalakult KD RFÜ belépése a koncepció készítés folyamatába segítette a kistérségi inputok beérkezését és a koncepció elfogadottságának növelését a régión belül.

Mindkét projektet tekintve megállapítható, hogy a kényszerkonzorciumok létrehozása nehézkessé teszi a tervezés megvalósítását. Lényeges különbségek érzékelhetők azonban a két projekt lebonyolításában, menedzselésében. A BRFT a projektet görgető, mozgató, sőt tervező, a projekt vezér szereplöjeként jelent meg. Ez abban is megmutatkozott, hogy valamennyi workshopon és Balaton Fejlesztési Tanács (BFT) ülésen a koncepció elöterjesztője a BRFT volt, a tervezők csupán meghívottként voltak jelen. A Közép-Dunántúlon másfajta szereposztás, pontosabban fogalmazva feladatmegosztás alakult ki. A projektgazda KDRFT csupán a projekt müködési kereteit biztosította, és részt vett a koncepciót formáló föbb rendezvényeken. A koncepcióval kapcsolatos közszereplések ,terhét”, a szakmai munka koordinálását a vezető tervezői feladatokkal megbízott NYUTI viselte, illetve látta el. A média- és térségen belüli kapcsolatok ápolását pedig a tervezési időszakban megalakult $\mathrm{KD}$ RFÜ végezte.

A fenti két projektnek volt a társadalmi részvétel, a kötelező egyeztetési eljárás szempontjából szakmailag is meghatározó jelentőségú újítása. Regionális szintü tervezési dokumentumokkal kapcsolatban elöször történt meg, hogy az írásban a koncepcióhoz beérkezett vélemények és javaslatok tételesen feldolgozásra kerültek. A különbözö szervezetek által küldött vélemények általában egy vagy több témakörhöz kapcsolódóan számos észrevételt tettek. A vélemények mindegyikét önálló javaslatként kezeltủk a feldolgozás során, majd a koncepció témakörei szerint rendezve egyenként, vagy csoportosítva válaszoltunk a felvetésekre. Témakörönként külön választottuk azokat a javaslatokat, amelyek beépítésre kerültek a dokumentumba. Ezek egy szövegváltozást mutató cellában a véleményt alkotók számára jól követhetők voltak. Az egyes témakörök végén a dokumentum szövegezését nem változtató, illetve a tervezök által nem befogadott vélemények indoklása helyezkedett el. Az így létrejött dokumentumok a koncepciók önálló mellékletét képezték (Grosz-Lados-Rechnitzer-Tóthné Hermann 1999). 


\section{Külföldi konzorciumok - hazai projektek}

Az elsajátítandó „EU-s leckék” sorába tartozott az egyes projektek kedvezményezettjének és végrehajtójának a szétválasztása. Adott projekt kedvezményezettje élvezi a megvalósult fejlesztés, elkészült tanulmány, terv hasznát. A részére megítélt támogatást nem kapja meg közvetlenül, az sohasem jelenik meg a számláján. A PHARE CBC Programirányító Irodával megkötött támogatási szerzódés, valamint a teljesítés igazolások alapján azt közvetlenül a projekt végrehajtója kapja. Az összeg átutalója pedig vagy közvetlenül a Programirányító Iroda vagy egy ún. keretszerződỏ szervezet (,framework contractor"). Ez a pénzügyi eljárás kizárja, hogy a kedvezményezett a megítélt projekttól eltérö célokra is felhasználhassa a támogatást.

A projekt végrehajtója (beruházás kivitelezője, tanulmány készítője) általában tender, bizonyos összeghatár felett az EU-ban is meghirdetett közbeszerzési eljárás keretében kerül kiválasztásra. Az 50000 euró-t meghaladó tervezési projektek esetében ezt a Keretszerződő szervezet bonyolítja. A projekt típusától függỏen a Brủsszelben regisztrált szakértỏ szervezetek és szakértők ún. ròvid listájáról (,short list") választ projektvezetôt, aki rendszerint valamely EU tagországból származik.

A kiválasztott projektvezető készíti el a feladat végrehajtásának módszertanát, amely tartalmazza a feladat megvalósításához szükséges szakértỏk számát, szakmai területeit és szükséges munkanap ráfordításait. A szükséges szakértőket a projekt vezetője választja ki, de a Keretszerződő szervezet köt azokkal szerződést. A kiválasztott szakértỏk többsége rendszerint szintén valamely tagországból származik. Magyarországi szakértőket, amennyiben rendelkeznek brüsszeli szakértői regisztrációs számmal, rendszerint helyi koordinátori feladattal bíznak meg. A szakmában eltöltött évek alapján a négy minőségi kategóriába sorolt szakértők díjazásában 1:2,5-3 arány mutatkozik a külföldi szakértők javára. Ez azt jelenti, hogy egy többségében külföldi szakértőkkel megvalósuló tervezési projekt 2,5-3-szor kevesebb időráfordítást bír el a hazai tervezőkkel bonyolított projektekhez képest.

Az uniós támogatással megvalósuló, nem beruházási jellegủ projektek egyik sajátossága eddig az volt, hogy a források egy jelentős hányada szakértői tevékenységeken keresztủl visszaáramlott a tagországokba. Így volt ez az 19951999-ös INTERREG II - PHARE CBC keretből megvalósuló projektek esetében is. A kisvállalkozás fejlesztés és a regionális politika témakörében, melyhez a területi tervezés is tartozik, a birminghami székhelyü West Middlands Enterprise (WMEB) nyerte el a PHARE országokban megvalósuló ilyen jellegü projektek lebonyolítását az 1994-1999-es időszakra. A jelzett időszakban a WMEB mintegy 500 projekt kezelését látta el a térség országaiban.

Ausztria taggá válását követỏen a Magyarország nyugati határszélén elhelyezkedő megyék is felhasználóivá válhattak ennek a Közösségi Kezdeményezési forrásnak. Később a programot kísérletképpen kiterjesztették nem EU-határ területekre is: 
magyar-román és magyar-szlovák határ-, illetve a magyar-osztrák-szlovák és a magyar-osztrák-szlovén hármashatár térsége (4. táblázat).

A PHARE CBC támogatás felhasználása ún. keretprogramokon keresztül történt. A keretprogramok az adott idöszakra meghatározták azokat a prioritásokat, tématerületeket, illetve az azok közötti forrásarányokat, amelyekre fel kívánták használni a támogatási keretet. Az oszták-magyar PHARE CBC program öt prioritás mentén szerveződött:

1. prioritás: Területi tervezés és fejlesztés (3\%)

2. prioritás: Mủszaki infrastruktúra fejlesztése (31\%)

3. prioritás: Gazdaságfejlesztés és együttmüködés (44\%)

4. prioritás: Emberi erőforrás fejlesztés $(9 \%)$

5. prioritás: Természet- és környezetvédelem (3\%)

\section{TÁBLÁZAT}

PHARE CBC programok Magyarországon

(PHARE CBC Programmes in Hungary)

\begin{tabular}{|c|c|c|c|}
\hline Program & Résztvevỏ magyar megyék & Partner régiók & $\begin{array}{l}\text { CBC forrás } \\
\text { (M euro) }\end{array}$ \\
\hline HU/AU 1996 & \multirow{5}{*}{$\begin{array}{l}\text { Csongrád, Békés, Hajdú-Bihar, } \\
\text { Szabolcs-Szatmár-Bereg }\end{array}$} & \multirow{5}{*}{ Burgenland } & 7,0 \\
\hline HU/AU 1997 & & & 11,0 \\
\hline HU/AU 1997 & & & 14,0 \\
\hline HU/AU 1998 & & & $(8,0)^{*}$ \\
\hline HU/AU 1999 & & & 10,0 \\
\hline Összesen & & & 42,0 \\
\hline HU/AU/SL 1995 & \multirow[b]{2}{*}{ Vas, Zala } & Dél- & 1.5 \\
\hline HU/AU/SL 1996 & & $\begin{array}{l}\text { Burgenland, } \\
\text { Muravidék }\end{array}$ & 1.5 \\
\hline Összesen & & & 3.0 \\
\hline HU/SK/AU 1995 & \multirow[b]{2}{*}{ Győr-Moson-Sopron } & Észak- & 1.5 \\
\hline HU/SK/AU 1996 & & $\begin{array}{l}\text { Kelet-Alsó- } \\
\text { Ausztria, Bécs, } \\
\text { Délnyugat- } \\
\text { Szlovákia } \\
\end{array}$ & 1.5 \\
\hline Összesen & & & 3.0 \\
\hline HU/SK 1999 & GY-M-S, K-E, Pest, Nógrád, B-A-Z & $\begin{array}{c}\text { Dél-szlovákiai } \\
\text { régiók }\end{array}$ & 2.0 \\
\hline Összesen & \multirow{4}{*}{$\begin{array}{l}\text { Csongrád, Békés, Hajdú-Bihar, } \\
\text { Szabolcs-Szatmár-Bereg }\end{array}$} & & 2.0 \\
\hline HU/RO 1996 & & Timis, Arad, & 5.0 \\
\hline HU/RO 1997 & & Bihor, Satu & 4.0 \\
\hline HU/RO 1999 & & Mare & 5.0 \\
\hline Ósszesen & & & 14.0 \\
\hline Mindösszesen & & & 64,0 \\
\hline
\end{tabular}

* Az Európai Bizottság döntése alapján átcsoportosítva az 1999. évi magyar-román és magyar-szlovák programokhoz.

B-A-Z: Borsod-Abaúj-Zemplén megye, GY-M-S: Györ-Moson-Sopron megye, K-E: Komárom-Esztergom megye

Forrás: FVM Területfejlesztési Phare Programirányító Iroda. 
A NYUTI több tervezési projekt megvalósításában vett részt, melyek közül az alábbiakban egy határ menti és egy, az egész Nyugat-dunántúli régiót átfogó projekt tapasztalatait összegezzük:

- Magyar-osztrák-szlovák közös területfejlesztési stratégia a hármashatár menti térségben (PHARE CBC ZZ952401-06-01)

- Nyugat-Magyarország területfejlesztési programja (PHARE CBC HU 99701 01-01 L001)

\section{Magyar-osztrák-szlovák közös területfejlesztési stratégia a hármashatár menti térségben}

A hármashatár stratégia az 1996. évi magyar-osztrák-szlovák PHARE CBC keret „Határon átnyúló kommunikáció fejlesztése” c. program keretében készuilt. Első számú célja az volt, hogy elkészítse a hármashatár térségének a következő EU tervidőszakra, a 2000-2006 közötti időszakra szóló fejlesztési stratégiáját, multiindikatív programját. A magyar oldalon zajló projekt tükör projektjeként, a szlovák oldalon ís zajlott a tervezés. Mindkét projekt 1999. év elején kezdődött, és a kezdeti fázistól szorosan együttmüködött a két tervezői csoport ${ }^{16}$.

A WMEB az ir Shannon Development tanácsadó céget, s azon belül Kevin $O$ 'Connor szakértöt kérte fel a magyar oldali projekt vezetésére és a NYUTI-t ajánlotta a projekttel kapcsolatos helyi koordináció megvalósítására. A projektvezető felelőssége volt a projekt munkacsoport összeállítása, a konkrét feladatok felosztása a szerzỏdésben rỏgzített 'Feladat-meghatározás' (Term of Reference - TOR) alapján. A projektvezetö egy 8 tagú nemzetközi csoportot kért fel a projektben való részvételre. A stáb néhány tagja a projekt elsỏ szakaszában (helyzetértékelés, SWOT analízis, jövőkép meghatározás) kapott több szerepet, míg mások inkább a későbbi fázisokban (projekt kiválasztás, projekt leírások /Project Fiche/, TOR-ok, logikai kerettervek /Logframe matrix/ készítése) kaptak szerepet. A projektvezető kivételével valamennyi külföldi résztvevő 20 szakértői napot fordíthatott a feladatára.

Az ilyen jellegủ projektekben kỏtelező ún. helyi koordinátor alkalmazása is, aki biztosítja a projekt team és a helyi szereplők közötti kapcsolatot. A NYUTI ennél szélesebb feladatkört látott el ebben a projektben. Ez részben a projekt koordinátori feladatok ellátását jelentette, továbbá a külföldi szakértők tématerületének megfelelö hazai szakértői háttér biztosítását négy NYUTI-s kutató részvételével. Lényegében így minden terület duplán képviseltetett a projektben. A projekt teamen belül nem alakulhattak kí horizontális kapcsolatok, csupán az egyes szakterületek mủvelői álltak egymással kapcsolatban. Ez biztosította, hogy a kủlföldi szakértő mögött legyen megfelelö helyismeret ${ }^{17} . \mathrm{Ez}$ az eröforrások pazarlásának tünik, amelyet a projekt időzavarba kerülése is alátámaszt ${ }^{18}$.

A szlovák oldali projekt esetében pont fordítottak voltak az arányok. A külföldi projekt team mindössze három föböl állt: projektvezető, projekt koordinátor és egy stratégiai tervezési szakértő. Az összes ágazati szakértőt a szlovák fél biztosította. 
Ebben kicsit közrejátszott a szlovák oldali projekt szükösebb költségvetése is. Ettől függetlenül, a megközelítés volt alapvetöen más. A helyi koordinátor biztosította a külföldi és a helyi szakértö csapat közötti kommunikációt, a munka jelentös hányadát pedig a helyi szakértők végezték.

\section{Nyugat-Dunántúl területfejlesztési programja}

$\mathrm{Az}$ időzavar még inkább kiütközött a másik tervezési projekt esetében. Az 1997. évi magyar-osztrák PHARE CBC keretböl finanszírozott „Nyugat-dunántúli régió területfejlesztési program" készítésére a WMEB a szakértói rövid listáról a londoni székhelyü Local and Regional Development Ltd. (LRDP) vezető munkatársát, Haris Martinost kérte fel a projekt vezetésére. A projektvezetỏ további két LRDP-s munkatársat, valamint két magyarországi szakértőt (MTA RKK NYUTI), részben helyi koordinátorként, részben a programdokumentum aktív formálójaként vont be a projekt megvalósításába.

Az 1999 áprilisában elindított projekt megvalósításának határideje 2000. április 30. volt. A projekt félidejénél a projekt kedvezményezettjét, a Nyugat-dunántúli Regionális Fejlesztési Tanácsot (NYD RFT) képviselő ún. Koordinációs Bizottság jelezte, hogy a programdokumentum készítéséhez több személyes kapcsolatot, konzultációt várnak a program készítőitől. Ezt a döntöen a külföldi szakértőkre szabott munkanap keret és a program költségvetése nem viselte el, hiszen ez bizonyos idöszakokban a külföldi szakértók folyamatos jelenlétét, valamint jelentös tolmácsolási költségek biztosítását igényelte volna.

A program megvalósítása ezért úgy módosult az NYD RFT 1999. október 6-i határozata alapján, hogy a külföldi szakértök a készülő program minöségéért és EU-konform tartalmáért felelősek. Ennek érdekében időszakonként konzultálnak a programdokumentum készítỏivel, valamint elkészítik a program ún. Egyeztetési Változatának ex-ante értékelését. A program készítésének feladatát az addig program koordinációs feladatokat ellátó MTA RKK NYUTI vette át az NYD RFT felkérésére. Ennek finanszírozására a kedvezményezettek pótlólagos forrást biztosítottak.

A térségi szereplök által igényelt konzultációk lényegesen meghosszabbították a projekt átfutási idejét. A program Egyeztetési Változata 2000 júliusára készült el, amelyet a hazai szabályozás által megkövetelt kötelezỏ egyeztetési eljárás követett. A külföldi szakértők feladatuknak megfelelöen elkészítették a program ex-ante értékelését, amelynek megállapításait, az azok alapján elvégzett módosításokat a program készítöi beépítettek a dokumentumba. A térségi szereplők által többszörösen áttekintett és javaslataikat beépítő programot a NYDRFT 2001 márciusi ülésén fogadta el mint a régió 2000-2006 közötti időszakra szóló területfejlesztési kulcsdokumentumát. A program az EU-s gyakorlatnak megfelelöen egyben a régió finanszírozási dokumentuma is az adott időszakra.

$\mathrm{Az}$ időben megtett beavatkozással egy, a régiós szereplők által is magukénak érzett program készült. Ugyanakkor jelzi a PHARE CBC ilyen típusú projektjeinek 
nehézkességét az által, hogy a Keretszerződő szervezet elsősorban az EU tagország szakértőire fordítja vissza az EU-s támogatást.

\section{Tapasztalatok-Eredmények}

A kötelező keretszerződó szervezet beléptetése egyszerủsíti a projektet megvalósítók helyzetét, hiszen a szerződéssel kapcsolatos adminisztratív feladatok (szerződések kezelése és követése, kifizetések és elszámolások) komoly terhét, a megbízókkal (PHARE CBC Programirányító Iroda) és a forrást biztosítókkal (Brüsszel) való közvetlen kapcsolattartás terhét leveszi azok válláról. Ugyanakkor jelentősen csökkenti a feladat végrehajtására rendelkezésre álló forrásokat is, mivel a munkadíjak 25-30\%-át tartja magánál a fenti feladatok ellátására ${ }^{19}$. Ez a hármashatár projekt 300000 euró-s büdzséjében kb. 55000 euró-t, míg a Nyugatdunántúli program 100000 euró-jából kb. 20000 euró-t tett ki.

A nagyszámú külfőldi szakértő alkalmazása jelentősen csökkenti a projekt megvalósíthatóságát, mert a 4 kategóriába sorolt viszonylag magas 450 és 787 euro között mozgó napi munkadijak, valamint az utaztatás költségei (repülójegy, szállás, napidij) összességében kevés munkanapot biztosít ezen szakértők számára. Így könnyen előfordulhat, hogy a munkák befejezetlenek maradnak, vagy arra számítanak, hogy a magyar partnerek elvégzik az elmaradt feladatokat, hiszen érdekük a projekt sikeres befejezése ${ }^{20}$.

A helyi koordinátor alkalmazása is kötelező ezekben a munkákban. A döcögös projektmenet ellenére mindkét esetben szakmai újdonságokat is tartalmazott mindkét projekt, pl.:

- projektgenerálás;

- a hazai és az EU-s tervezési követelmények, irányelvek összehangolása.

a) A hármashatár projektben fontos elem volt a helyzetelemzésnek és a jövőképnek a helyi szereplökkel történỏ közös formálása és határon átnyúló hatású projektek generalása. Másképpen fogalmazva, a projekt megvalósítása során az alulról induló tervezés ('bottom-up') elvét kellett alkalmazni. A projekt indító szakaszában 4-4 ún. helyi, illetve ágazati workshop került megrendezésre a fenti célok érdekében. Egy egyszerủsített projekt-ötletlap segítségével a workshopok helyszínén leírt, vagy később írásban vagy elektronikus úton megküldött projektjavaslatokból egy közel 80 ötletet tartalmazó adatbázis jött létre.

További feladatként jelentkezett, hogy ebbỏl a projekt listából kiválasztásra kerüljön 10-12 olyan, az új PHARE CBC szabályoknak megfelelő, legalább 2 millió euró összegü projekt, amelyek a 2000-2006 közötti INTERREG III PHARE CBC programidószak nagy projektjei lehetnek magyar-osztrák vagy magyar-szlovák viszonylatban. Két lépcsỏben, egy külföldi szakértỏ segítségével 14 olyan projektjavaslatot sikerült azonosítani, amelyek

- egyfelöl egyaránt összhangban voltak a hármashatár térségre megfogalmazott jövőképpel, a Nyugat-Dunántúl akkor formálódó, ugyanezen időszakot átfogó 
területfejlesztési programjának, illetve a Györ-Moson-Sopron megye területfejlesztési koncepciójának célkitủzéseivel;

- másfelöl megfeleltek a PHARE CBC követelményeknek (határon átnyúló hatás, projek't méret), illetve megfelelő elökészítettséggel rendelkeztek ahhoz, hogy a projekt az idöszakon belül megvalósítható legyen, pl. különböző, a projekt megvalósításához szükséges tervezési dokumentumok - megvalósíthatósági tanulmány, üzleti terv, szabályozási terv, kiviteli terv, engedélyezési terv stb. - már elkészültek, folyamatban voltak, elkülönült menedzsment szervezet foglalkozott a projekttel, érzékelhető volt a projekt hosszú távú pénzügyi fenntarthatósága.

Ez a projektgenerálási és kiválasztási rendszer megelözte a hazai gyakorlatot, hiszen ennek a módszernek az alkalmazása csak napjainkban kap majd kulcsszerepet a Nemzeti Fejlesztési Terv (NFT), illetve az azt alkotó Ágazati Operatív Programok és a Regionális Operatív Program kidolgozása során.

A fentieken túl a hármashatár stratégia készítésének egy hosszabb távon fontossá váló plusz hozadéka is volt a NYUTI számára. A közös munka egy kapcsolatrendszer kialakulását eredményezte szlovák partner szervezetekkel, amelyek jótékony hatással lehetnek mind a magyar-szlovák határ-, mind a hármashatár térségében kialakuló közös területfejlesztési kutatásokra, fejlesztési dokumentumok készítésére, a határ menti területfejlesztési együttmüködési kezdeményezésekre.

b) A Nyugat-dunántúli területfejlesztési program szakmai újdonságai több összetevőböl is táplálkoznak. A legfontosabb ezek közül a program szerkezetének olyan megformálása, amely összhangban van a területfejlesztési programok készítésének mind a hazai szabályozásával ${ }^{21}$, mind az EU Strukturális Alapok tervezésére vonatkozó irányelveivel ${ }^{22}$. Ez utóbbi azért vált hangsúlyossá ebben a programban, mert az deklaráltan a régió 2000-2006 közötti időszakra szóló fejlesztési dokumentumaként készült. Ebben az esetben figyelemmel kellett lenni arra, hogy a Strukturális Alapokra vonatkozó szabályok érvényesüljenek a programban.

A problémát az okozta, hogy a hazai szabályozás - annak ellenére, hogy 1998-ban készült rendeletröl van szó - nem vette át az EU-ban alkalmazott programozási terminológiát. Így a hivatkozott miniszteri rendelet stratégiai és operatív programokat kér számon a hazai dokumentumokon, míg az EU irányelvek stratégiai és operatív célokról, prioritásokról és intézkedésekről szólnak.

A helyzetet bonyolította az addigi hazai gyakorlat is. Az etalonként emlegetett, 1999. július 30-án elfogadott Dél-dunántúli komplex területfejlesztési program igyekszik megfelelni a rendeletben elöírtaknak. Szétválasztja a stratégiai programot és az operatív programot. Előbbire azonban csupán általános leírást ad, $s$ nem követi végig a rendeletben meghatározott részfeladatokat. Az operatív program sokkal részletezöbb. Azonban ez is csak nagyjából egyezik meg a rendelet egyes pontjaiban megfogalmazottakkal. Az egyes operatív programok 
kibontása inkább a PHARE programok rendszerét követi. Az alkalmazásban azonban nem következetes, mert az egyes operatív programok nem egységes szerkezetủek, vagy ugyanazon elemeket más és más sorrendben tárgyalja két egymást követö programnál.

Még érdekesebb a helyzet a PHARE 2000 programba került régiók fejlesztési programjaival, hiszen azok egyáltalán nem követik a hivatkozott miniszteri rendeletet (EU forrás - EU-s programozási irányelvek érvényesülése!). A DélAlföld PHARE 2000 programjának 2000. januári változata stratégiai célt (Strategic Aim), stratégiai célkitüzéseket (Strategic Objectives), prioritásokat (Priorities) és intézkedéseket (Measures) definiál. Lényegében az intézkedéseket bontja ki olyan szinten, amit a miniszteri rendelet is elvár, de attól eltérö, inkább az EU programozási irányelveit alkalmazva (Dél-Dunántúl is hasonló szerkezetben dolgozott).

A hazai és az EU-s szabályozás eltéréseiböl fakadó problémákat mind a régiós, mind a nemzeti szereplök számára elfogadható módon sikerült megoldani a NyugatDunántúl esetében. A regionális PHARE 2000 programokat felváltó ERFP-k 2000 májusában kiadott tervezési irányelvei teljes egészében megegyeztek a Nyugatdunántúli régió területfejlesztési program készítése során kialakított szerkezettel!

A helyzetértékelö szakaszban két újítást is bevezetett a NYUTI. A külsö környezet hatásainak értékelésénél regionális szintủ területfejlesztési dokumentumban elöször jelent meg az Európai Területfejlesztési Perspektíva (European Spatial Development Perspective - ESDP) és a Nyugat-dunántúli régiót is magában foglaló európai nagytérségre, a CADSES térségre készült területfejlesztési stratégia, a Vision Planet dokumentumnak a térség fejlesztése számára fontos elemeinek kiemelése. Ezzel még hangsúlyosabbá kívántuk tenni, hogy a régió területfejlesztési programja nem csupán az előcsatlakozási, hanem a csatlakozást követö időszakra is hordoz üzeneteket.

A programdokumentum helyzetértékelő szakaszában szereplő másik újítás az uniós területfejlesztési dokumentumokban alkalmazandó, az előző időszak döntéseire vonatkozó értékelés elkészítése volt. A régió szintjén az 1998-2000 között rendelkezésre álló források csak a régió jövőjét megalapozó tervezési dokumentumok elkészítésére, illetve kisebb léptékü szervezeti fejlesztésre voltak elegendỏek. Ennek tükrében az elemzés inkább a régiót alkotó megyék számára 1996-2000 között rendelkezésre álló területfejlesztési források felhasználását vette célba. Fö konklúzióként megállapítható, hogy az évtized közepén készült megyei koncepciók intézkedései csak kismértékben tükröződtek vissza a támogatások felhasználásában. Azok döntỏen infrastrukturális és gazdaságfejlesztési célokat szolgáltak. Ennek oka a felosztható források központi szabályozása, amely nem törekedett a megyei koncepciók célrendszerének számbavételére a felhasználási célok kijelölésénél. A sok megyei koncepcióban kulcselemnek tekintett humánerőforrás-fejlesztést csupán a decentralizált TFC 2001. évi szabályozása tette lehetỏvé en $^{23}$. 
Végül a Nyugat-Dunántúl területfejlesztési program az első olyan régiós dokumentum, amely alkalmazta az ex-ante értékelést a programdokumentum végső megfogalmazásakor. A külföldi szakértő elkészítette program egyeztetési változatának az EU irányelvei szerinti ${ }^{24}$ ex-ante értékelését, amelyet önálló fejezetként beépítettünk a programdokumentumba. Az értékelésben kifogásolt vagy hiányolt elemeket javítottuk, illetve pótoltuk. A megvalósított változtatásokat az ex-ante értékelés megfelelö bekezdéseinél zárójelben jeleztük. Mellékletben rögzítettük az elkészített értékelés metodikáját is.

\section{Külföldi konzorciumok - Transznacionális projektek}

Az ESDP formálása során az Európai Bizottság az Uniót és közvetlen szomszédságát földrajzi-geopolitikai alapon nagytérségekre osztotta fel. Az 19941999 közötti programidöszakában a Bizottság kiemelt figyelmet fordított az európai nagytérségek hosszú távú fejlődési lehetöségeinek felvázolására. Így az időszak alatt, döntően a transznacionális együttműködéseket támogató INTERREG IIC Közösségi Kezdeményezés segítségével sorra készültek a nagyrégiós jövőképek. Ezek sorában az évtized elsö felében a Balti térségre készített VASAB 2010 dokumentum volt az elsö. A közös jövőképben megfogalmazottak elösegítésére Rostockban és Gdanskban titkárságot létesítettek az együttmủködésben érdekelt államok. Az ezredfordulóra már a koncepció megújítását is megtették VASAB $2010+$ elnevezéssel. Ebben a dokumentumban már a jövöképet megvalósító lehetséges projektek is megtalálhatók.

A Duna-völggyel a szívében a Bizottság két nagytávú koncepció készítését is támogatta. Az INTERREG IIC keretei között egy osztrák és egy német kezdeményezés összevonásával indult 1998 elején a Vision Planet projekt német vezetéssel (Bundesamt für Bauwesen und Raumforsung - BBR). A Bizottság XVI. Területfejlesztési Föigazgatósága közvetlen támogatásával, az osztrák Österreichische Institut für Raumforsung (ÖIR) vezetésével pedig Danube Space Study címen indult program. A Vision Planet projektben az RKK és a VÁTI képviselte Magyarországot, illetve az RKK- $n$ belül a NYUTI vett részt a Munkacsoport munkájában, míg a föigazgató a Szakértö Csoport tagja volt. A Danube Space Study-ban, a VÁTI visszalépését követöen a NYUTI képviselte Magyarországot.

Jelen tanulmánynak nem célja a két projekt eredményeinek bemutatása ${ }^{25}$. Figyelmünket a tervezỏi konzorciumok müködésére fordítjuk. A két projekt esetében a tervezỏi csapat szervezésének módjában és a szakértők szerepében is jelentős eltérés volt. A Danube Space Study elkészítésére kifejezetten a bécsi ÖIR kapott megbízást. Mivel a projekt nem Közösségi kezdeményezésként indult, ezért a projekt által érintett országok INTERREG vagy PHARE CBC forrásai kevéssé voltak mobilizálhatók más országok szervezeteinek a projektbe történỏ bevonására. Így az ÖIR országonként egy-egy neves szakértőt igyekezett megnyerni a projektben való részvételre, akikkel egyénileg kötött megbízási szerződést. 
A Vision Planet szervezetrendszere az INTERREG forrás miatt eleve bonyolultabb volt, hiszen a projekt mögött különböző szintủ szervezetek húzódtak meg eltérő feladatokkal. A Munkacsoport szakmai irányítását és koordinációs feladatait a német $B B R$ látta el. A három éves átfutási idejủ projekt szakmai vezetésére Illés Ivánt, az RKK akkori föigazgatójât kérték fel. Tehát a német fél mindenképpen arra törekedett, hogy a közép-kelet-európai térséget belülről ismerő szakember vezesse a projekt szakmai részét. Az egyes országokat képviselő tervező szervezeteket, az adott ország területfejlesztésért felelös minisztériuma, vagy az INERREG IIC ügyekért felelös hivatal jelölte meg és kérte fel a projektben való részvételre. (Magyarország esetében ez az FVM, illetve az FVM Phare Programirányító Iroda volt.)

A részt vevő tervező szervezetek közös munkában való részvételének finanszírozási háttere eltérő volt. Egyes országok esetében az adott minisztériumhoz tartozó tervezỏ intézet (pl. Romániában a bukaresti Urbanpoiect, Lengyelországban a katowicei Stratégiai Tanulmányok Kormányzati Központja Regionális Fejlesztési Irodája, vagy Bulgáriában a Regionális Fejlesztés és Lakáspolitika Országos Központja), vagy közvetlenül minisztériumi tisztviselök (pl. Szlovénia, Horvátország) vettek részt a munkában. Esetükben a részvétel pénzügyi hátterét az adott szervezet aktuális költségvetése biztosította. Más esetekben (pl. Csehország, Magyarország és Szlovákia, valamint az EU tagállamok) INTERREG IIC PHARE CBC és nemzeti társfinanszírozási forrásokkal biztosították részvételüket a projektben.

A rêszt vevő országok, a finanszírozási háttértöl függetlenül egyenrangú partnerként vettek részt a Vision Planet Munkacsoport, illetve a Project Panel munkájában. A startvonalnál felsorakozó országok mindegyike egységes vázlat mentén elkészítette a saját ország tanulmányát. A következö lépésben 16, az egyes ország tanulmányokat figyelembe vevő horizontális tanulmány készült. A témákat a részt vevő országok közös megegyezéssel felosztották egymás között. Ez a munka további menetében is az egyenrangú részvételt biztosította. A következő lépések már a jövőépítỏ dokumentum megformálásához kapcsolódtak, melynek munkaanyag változatát Illés Iván készítette el, $\mathrm{s}$ ezt több lépcsőben alakította ki a projekt több szinten múködő rendszere. A Vision Planet szélesebb körü megismertetését két konferencia is segítette (Trieszt, 1999. június 30. és Pozsony, 2000. január 13-14.). Az érintett országokon belül a Vision Planet megismertetése a szakmai közvéleménnyel a projektben részt vevő tervezők és a felelős minisztériumok közös felelőssége volt.

A Danube Space Study megvalósítása során az alapot szintén az ország értékelések biztosították. A fentiekkel szemben azonban a felkért nemzeti szakértők nem egy közös vázlat szerinti tanulmánnyal járultak hozzá a munkához, hanem az adott országokról készülő jelentésekhez szükséges idősoros demográfiai, gazdasági és különböző ágazati adatokat biztosították a tanulmányokat megíró ÖIR munkatársak részére. Szerepük tehát az adatszolgáltatásra és a visszajelzésre korlátozódott. Az ÖIR által megírt ország tanulmányokat és a készülő Danube 
Space Study Dokumentumot véleményezték részben elektronikus úton, részben két workshop keretében (1999. május: Szenc, Szlovákia; 1999. október: Kisinyov, Moldávia).

Az elfogadás szintjei is eltértek a két projekt tekintetében. A Danube Space Study-t mint közvetlen bizottsági projektet, a megbízást kiadó XVI. Területfejlesztési Főigazgatóság felügyelte és fogadta el. A Vision Planet esetében a Project Panelnek mint a CADSES térség területfejlesztésért felelös minisztériumait tömörítö, a projektet felügyelő szervezetnek volt kulcsszerepe. A Project Panel által 2000. január 12-én az ausztriai Schwechaton megfogalmazódott egy nyilatkozat, a munkában részt vevö országok közös politikai nyilatkozata arról, hogy a Vision Planet a CADSES térségre kidolgozott területfejlesztési együttmüködés legfontosabb célkitüzéseit és politikai javaslatait tartalmazó dokumentum. Természetesen mint a finanszírozást biztosító föhatóságnak, a projektvezetés rendszeresen beszámolt a brüsszeli Bizottságnak is a projekt menetéről.

\section{Programozással az uniós forrásokért}

Napjainkra valamennyi térségi szint (régió, megye, kistérség) rendelkezik a jövőjét meghatározó fejlesztési koncepcióval, stratégiával. Ezek a hosszabb időtávra megfogalmazott tervek nem alkalmasak arra, hogy egy konkrét támogatási rendszer, mint pl. az EU Strukturális Alapok felhasználásának finanszírozási dokumentumai legyenek. Ezt a szerepet a programozás, a területfejlesztési stratégiai és operatív program tölti be.

Magyarország a csatlakozáskor teljes egészében 1. célterületnek minösül majd az EU regionális politikájában. Így a csatlakozásig el kell készíteni azt a dokumentumot, amelyet a magyar kormány kíván benyújtani az Európai Bizottsághoz a támogatási kérelemmel együtt, amely a Közösségi Támogatási Keret kidolgozásának alapjául szolgál majd. Ez a dokumentum a Nemzeti Fejlesztési Terv (NFT), amely egy széles körben egyeztetett és elfogadott ágazati és regionális célrendszert egyaránt integráló, a tevékenységeket és a forrásokat koordináló középtávú stratégiai program (Faragó 2000).

Az EU Elöcsatlakozási Alapok (PHARE, ISPA, SAPARD) felhasználhatóságának megteremtése indította el az egyes területfejlesztési szintek programozási tevékenységét. 1999-től felerösödött a regionális részvétellel zajló nemzeti szintü területi tervezés (Átfogó Fejlesztési Terv-ÁFT, Elözetes Nemzeti Fejlesztési TervENFT, NFT - 1. táblázat), a területi tervezés minden szinten permanens folyamattá válik, ami az éves szintủ finanszírozási döntések következtében 2006-ig így is marad. 


\section{Területfejlesztési programok a régiók és a megyék szintjén}

A programozás során a kihívást a hazai és az EU szabályozás összehangolatlansága, illetve a Strukturális Alapokra történő felkészülés lehetősége jelentette. Mivel az ország egésze az 1. célterület alapján lesz támogatható, az NFT területi mélysége a NUTS 2 szint, azaz a régiók. A 2. célterület alapegysége a NUTS 3 szint lenne, azaz a megyék, de mivel az ország egésze az 1. célterület alapján válik támogathatóvá, e keretek között kell megoldani a szerkezetátalakítással küszködő megyék problémáit is (Faragó 2000).

Míg a koncepció-alkotás az előző évtized végére végigszaladt a területfejlesztés egyes szintjein, addig a programozás csak a régiókban és néhány megyében kezdődött el. A régiók a 2000-től indított PHARE Elöcsatlakozási Alap felhasználása érdekében, egységes irányelvek mentén már 1999 júliusában megkezdték fejlesztési stratégiai programjuk kidolgozását. Mivel a megyéknek nem füződött közvetlen pénzügyi érdekeltsége sem az Elöcsatlakozási Alapokhoz, sem a Strukturális Alapokhoz, ezért a megyék kevéssé fordítottak figyelmet koncepcióik programdokumentummá alakítására. Kivételt képeznek a Nyugat-dunántúli megyék, ahol a régió mindegyik megyéje és maga a régió is elkészítette hosszú távú fejlesztési koncepcióját az előző évtized végére. Zala megye ugyanezen időszakra már fejlesztési programot is készített a korábban kidolgozott koncepciója alapján.

PHARE CBC támogatással 1999 áprilisában megkezdődött a régió, majd a régiós TFC forrásokból 2000. januártól Györ-Moson-Sopron és Vas megye területfejlesztési programjának kidolgozása. Mindkét megyei programot a NYUTI készítette. 2001. januárban a KD RFÜ jelezte, hogy a rövidtávra szóló Elözetes Regionális Fejlesztési Program (ERFT) szeretné a teljes 2000-2006 közötti időszakot átfogó fejlesztési programmá alakítani. A NYUTI mindegyik programnál a Nyugat-dunántúli programra 2000. áprilisban kidolgozott stratégiai és operatív program keretrendszerét alkalmazta.

A régiós programok esetében nem volt szükség vadonatúj helyzetelemző anyagok készítésére, hiszen egyfelől mindkét régió friss fejlesztési koncepcióval rendelkezett. Ugyanakkor az 1998-tól az egyes régiók rendelkezésére bocsátott decentralizált TFC források nagysága (1998: $60 \mathrm{MFt}$, 1999: $130 \mathrm{MFt}$ és 2000: 100 MFt) valójában csak az egyes régiók számára kiemelkedően fontos ágazati és horizontális tervek elkészítésére voltak elegendỏek. A Nyugat-Dunántúlon szinte párhuzamosan futott a kisebb léptékủ ágazati tervek és a regionális program készítése. Így a tervezők a program minden egyes intézkedése mögé egy-egy ágazati stratégiát vagy programot tudtak felsorakoztatni (Lados 2001a). A tervezés során folyamatos oda-vissza irányú kapcsolat volt a régió párhuzamosan készülő PHARE 2000, majd ERFP dokumentumával.

A Közép-Dunántúlon más volt a kiinduló helyzet. A KD RFÜ akkor bízta meg a NYUTI-t egy, a teljes Strukturális Alapok aktuális tervidőszakát lefedő stratégiai program elkészítésére, amikor a régió már számos, a koncepcióban meghatározott részprogramot, sőt a Közép-dunántúli ERFP-t is elkészítette. A feladat ez esetben a 
régió hét évet átfogó, az EU tervezési rendszerével kompatibilis programdokumentum összeállítása volt (Lados 2001c). Éppen ezért a Nyugat-dunántúli program 2 éves átfutási idejével szemben a Közép-Dunántúl esetében 6 hónap elegendö volt a munka lebonyolítására.

A két megyei program elkészítése lényegében a koncepciók aktualizálásával indult, hiszen a Györ-Moson-Sopron megyei koncepciót még 1996-ban fogadta el a megyei önkormányzat, majd az MTT. A dokumentum még a kilencvenes évek első felének helyzetelemzésére támaszkodott. Az eltelt fél évtized pedig éppen a területfejlesztésben hozott jelentös változásokat egy-egy megye életében: megalakultak az MTT-k, a megyékhez decentralizált területfejlesztési források müködtetésében már több éves tapasztalat halmozódott fel stb. A vizsgálatok középpontjában az állt, hogy a kilencvenes évek elején megrajzolt trendekhez képest történt-e gyökeres változás vagy törés a megye társadalmi-gazdaságikörnyezeti folyamataiban. Szükséges-e az 1996-ban megfogalmazott jövökép "Györ-Moson-Sopron megye a hazai modernizáció zászlóshajója" újrafogalmazása? Az elvégzett elemzések azt igazolták, hogy nem.

A másik lényeges irány az volt, hogy a megyei program mint finanszírozási dokumentum olyan intézkedéseket tartalmazzon, amelyek megvalósítása az MTT által kezelt források felhasználásával lehetséges. Figyelemmel kellett lenni azonban arra is, hogy egyes nemzeti célelöirányzatok a pályázókon számon kérik azt, hogy projektjavaslatuk összhangban van-e a megyei koncepcióval. Így néhány intézkedés kifejezetten ennek a célnak megfelelve került a programba (Lados 2001b).

Meg kellett találni annak egyensúlyát is, hogy a régió és a megyei programok hogyan viszonyulnak egymáshoz. A régió program bár alulról is építkezik, nem jelenti a megyei programok összegzését, integrálását. Minden területfejlesztési szint számára meghatározható, milyen típusú fejlesztések megvalósítása kezelhető az adott szinten. Erre a területfejlesztési törvény nem kínált megoldást, mivel az RTT-k és az MTT-k feladatkörét egymást teljes mértékben átfedve határozta meg. Csupán a TFC 2001. évi szabályozása tett kísérletet arra, hogy hasonló feladatok esetén meghúzza a határt a megyei és a régiós kompetencia között (pl. a munkahelyteremtő beruházások esetében a kis létszámú fejlesztések a megyei, míg a nagyobb, 50 fö́t meghaladó fejlesztések inkább a régiós TFC-ből támogatandók).

Sajnos a források régiók és megyék közötti eddigi elosztási gyakorlata sem ad megfelelő fogódzót egy általánosan érvényesíthetô rendszerre. Ha valamely szint mindegyike esetében jelentôs forrástöbblet lenne a másik szinttel összehasonlítva, akkor valóban a projektek nagyságrendje alapján lehetne szétválasztani a funkciókat. 2000-ig a régiók lényegesen kevesebb forráshoz jutottak, mint a megyék. 2001-től a Strukturális Alapokra történö fölkészuilés érdekében a régiók 1,0-2,5 Mrd Ft decentralizált támogatással számolhatnak. Az egy före jutó GDP alapján hazai viszonylatban fejlett régiók esetében ez akkora forrást jelent, mint az alkotó megyék együttes forrása a TFC-böl, a TEKI-böl és a CÉDE-böl. Tehát koncentráltan, viszonylag nagy, a régió egészére kiható projektek is támogathatóvá válnak. 
A kiegyenlítési politika kedvezményezettjei jelenleg a kistérségek és a megyék. A forrásallokáció ebben a tekintetben a megyei területfejlesztési tanácsokhoz utalt TEKI-n keresztül valósul meg. Az elmaradott/válság térségekkel terhelt megyék Békés, Borsod-Abaúj-Zemplén, Nógrád, Somogy, Szabolcs-Szatmár-Bereg esetében az MTT-k éves forrása 2001-ben is meghaladja az adott régió költségvetését.

A csatlakozást követỏ idöszakban inkább a hazai fejlett régiókban lévő helyzet vetíthető elöre: a régió támogatási lehetőségei többszörösen meghaladják majd az alkotó megyék összesített területfejlesztési forrásait. Ez azt jelenti, hogy a támogatott programok/projektek nagysága mentén lehetne meghúzni a két szint feladatai közötti különbséget. Így a régió támogatná a nagyobb léptékủ, a régió jelentős részére kiható humáneröforrás-, gazdaság- és egyéb fejlesztési projekteket (pl. ipari parkok, innovációs központok, logisztikai központok stb.), míg a megyei szint kisebb és elaprózottabb forrásai a megyén belüli kiegyenlítést segítené ugyanezekben az ágazatokban.

Ez azt is jelenti, hogy a megyei program nem beágyazódik a régió programba, nem részhalmaza annak egy tervhierarchia mentén, hanem egymást kiegészító elemei a területfejlesztésnek. A közös pontoknak a célrendszerben kell visszaköszönnie. Kedvezö, ha az egyes megyék jövöképe és stratégiai céljai összhangban vannak a régiós jövőképpel és stratégiai célokkal. A megyék és a régió prioritás és intézkedés rendszere hasonló szerkezetet követ, de a hangsúlyok az eltérő adottságok és fejlesztési igények miatt eltérỏek. A rendelkezésre álló források következtében a hasonló célkitüzések beavatkozási területei, célcsoportjai, kedvezményezettjei, projekt kiválasztási kritériumai szintén eltérnek a régió és a megyék szintjén (Lados 2001a).

A Györ-Moson-Sopron megyei programban igyekeztünk biztosítani az összhangot a régió jövőképével („Közép-Európa egyik vezetö régiója születik”), ugyanakkor a megye sajátosságait és forrásbázisát figyelembe vevő dokumentumot készítettünk. A mérsékelt forráslehetőségek miatt a megyei modernizáció fókuszába a kisvárosok, a kistérségi központok és a községek fejlesztését helyeztük. A nagyobb léptékủ, nagyobb forrásigényú projektek megvalósítását a régiós, illetve a nemzeti erőforrásokból tartottuk megvalósíthatónak.

\section{A régiók szerepe az NFT kidolgozásában}

Az NFT, majd az Európai Bizottsággal közösen készített Közösségi Támogatási Keret véglegesítéséhez szükséges annak tisztázása is, hogy milyen típusú akciók, fejlesztések történjenek az országos szintủ ágazati programok keretében, továbbá melyek tartoznak a regionális szint tervezési és megvalósítási kompetenciájába. Ennek meghatározása és szabályozása a magyar kormány feladata. Az Európai Bizottság ugyanis a tervezést a tagállam kompetenciájába utalja (Faragó 2000). Az NFT-ben központi feladatként megjelenő fejlesztéseket operatív programokká kell formálni, és kezdeményezni kell, hogy ezek beépüljenek az alsóbb szintü 
Lados Mihály: A területi tervezés kihívásai a kilencvenes években Magyarországon:

A területfejlesztési stratégiák kialakitásáról a programozásig és az értékelésig. Tér és Társadalom, 15. 2001. 2. 25-69. p

programokba (Horváth 1998). De ez visszafelé is igaz, vagyis a nemzeti szintü tervezési dokumentumban vissza kell tükröződnie a régiók felöl érkezö, országos szinten megoldható igényeknek (Callanan-Lados 2001).

A Strukturális Alapok fogadására történő felkészülést, s ezen belül az NFT megalapozását szolgálja a Speciális Felkészítési Program (Special Preparotory Program - SPP). Az SPP, a képzést tekintve a terúletfejlesztés nemzeti és kisebb mértékben a regionális szakemberekre irányul. Az SPP tervezési blokkja pedig az NFT és azon belül az ágazati és regionális operatív programok előkészületeit segíti.

Az EU gyakorlatában az NFT-t az adott ország által meghatározott Ágazati Operativ Programok (Sectoral Operative Program - SOP) és az 1. célterületbe sorolt régiókra egyenként készitett Regionális Operativ Programok (Regional Operative Program - ROP) jelentik. Ez Magyarországot tekintve 7 ROP-ot jelentene. Az Európai Bizottság szerint a hazai régiók jelenleg még felkészületlenek és nem rendelkeznek megfelelö kapacitásokkal ahhoz, hogy a Strukturális Alapok felhasználását menedzseljék. Bizalmatlanságukat növeli, hogy statisztikai régióink mögött nincsen politikai legitimitás, mivel az RFT-k nem választott testületek. Ezért a Bizottság 2000 tavaszán azt ajánlotta a magyar kormány számára, hogy az NFT- $n$ belül csupán egy ROP készüljön. A Bizottság ezt az ajánlást Lengyelország kivételével valamennyi csatlakozó ország számára megtette.

A döntésnek valóban vannak a folyamatokat segítő, a döntési helyzeteket könnyítő vonásai. A tagországokat tekintve jelenleg 57 régió tartozik az 1 . célterület kedvezményezettjei közé. Ezek mindegyike rendelkezik önálló ROP-pal. A csatlakozó országok további közel 50 régióval növelnék ezt a számot. Ez változatlan brüsszeli adminisztrációs létszám mellett jelentỏs torlódást okozhat az NFT Kỏzösségi Támogatási Keretté alakítása során. A gyorsabb adminisztrációt, a Strukturális Alapok és a Kohéziós Alap megkezdhető felhasználását segittheti, ha 50 ROP helyett csupán a lengyel régiók és 9 ország egy-egy ROP-ját kell egy időben tárgyalnia a Bizottságnak és az érdekelt kormányoknak. Az pedig már az egyes országokon múlik, hogy az eddig kialakult területfejlesztési szinteket mennyire tekinti partnernek az NFT kimunkálása során.

A tervezés jelen szakaszában kikristályosodni látszik, hogy 4 SOP és 1 ROP fogja alkotni a magyar NFT-t. Nem szabad azonban ezt a magyar régiók egyfajta diszkriminációjaként vagy az eddigi hazai decentralizációs folyamatok derékba töréseként megélni. Egy 2004-ben bekövetkező csatlakozás esetén valóban rövidnek tủnik az a 18 hónap, amely rendelkezésre áll ahhoz, hogy Magyarország 2004-ben projekteket valósítson meg a Strukturális Alapok felhasználásával.

Nyilván nehéz érzelmileg azonosulni egy ilyen döntéssel, miközben maga az Unió az elmúlt 10 év PHARE kisérleti területfejlesztési, illetve CBC programjain keresztül a decentralizációra készítette fel a hazai szakembereket. A területfejlesztésre koncentrálva óriási kapacitások épültek ki a hazai felsőoktatásban és a felnőtt képzésben az elmúlt évtizedben. Joggal érezhetjük úgy, hogy van megfelelő szellemi potenciál, amiből regionális szinten is meriteni lehet az uniós és a hazai területfejlesztési politika régiók szintjén történő menedzselésére. 
Az RFT-ék Monitoring Bizottsággá (Monitoring Committee), illetve az RFÜ-k Irányító Szervezetté (Managing Authority) alkalmassá tétele az új évtized elején megakadt. A RFƯ-k többsége sem létszámában, sem szakember összetételében nem alkalmas jelenleg a szükséges funkciók ellátására. Ebben a helyzetben a régiók számára a feladat az, hogy a 2006-ig tartó ciklusban minél aktívabban kapcsolódjanak az NFT előkészítésébe. Ezzel párhuzamosan azonban kormányzati szinten szükséges annak a politikai akaratnak a kinyilvánítása, amely intézkedéseivel segíti, hogy a hazai régiók 2007-töl valóban alkalmassá váljanak a Strukturális Alapok felhasználásának menedzselésére.

A régiók aktív részvételének egyik módja a Regionális Cselekvési Terv (Regional Action Plan - RAP) készítése. Az SPP Non-Twinning program keretében az NFT tervezéséhez kapcsolódóan szerepelt egy minta ROP kidolgozása. Ennek minta területéül a kormányzat a Közép-Dunántúlt jelölte ki. Ez a mintaprojekt azonban elmaradt, hiszen egy nemzeti szinten összefogott ROP esetében erre nincsen szükség. A figyelem középpontjába így az került, hogy az egyes régiók miképpen tudnak hozzájárulni az NFT és azon belül a SOP-ok és a ROP kidolgozásához. A régiók bevonását - bármi nemủ centralizációs törekvés ellenére - az ösztönzi, hogy a Bizottság elvárása szerint az NFT-nek alulról érkező kezdeményezésekre kell épülnie.

Ez a gyakorlatban azt jelenti, hogy a tervet a Bizottság akkor tartja megvalósíthatónak, ha rendelkezik egy olyan projektlistával, az uniós szakzsargonban 'project pipeline'-nal, amelyek megfelelnek a Strukturális Alapok felhasználási kritériumainak és folyamatosan indíthatók a tervidöszak során (Callanan-Lados 2001). Ezek a projektlisták egyaránt tartalmazhatnak inputokat az egyes SOP-ok és a nemzeti szinten összefogott ROP számára. A fentiek tükrében döntött úgy a területfejlesztési kormányzat, hogy az elmaradó minta ROP helyett egy minta Regionális Cselekvési Terv készüljön a már korábban kiválasztott Közép-Dunántúlra. A projektben helyi szakértöként a NYUTI-t kérte föl az SPP Non-Twinning program irányító testülete.

\section{A Közép-Dunántúl minta Regionális Cselekvési Terve}

A projekt az alábbi célkitüzéseket kívánta megvalósítani (Callanan-Lados 2001):

- Egy a régió jövöképét, hosszú távú területfejlesztési célkitüzéseinek elérését segítő projekt adatbázis létrehozása;

- A mintaprojektnek a régión belüli partnerségi kapcsolatok segítségével történö lebonyolítása;

- Projekt kiválasztási módszer kidolgozása;

- A régió abszorpciós kapacitásának felmérése;

- A Közép-dunántúli régió területfejlesztési program intézkedésrendszerének tesztelése;

- A régió programdokumentumának formálása. 
Lados Mihály: A területi tervezés kihívásai a kilencvenes években Magyarországon:

A területfejlesztési stratégiák kialakitásáról a programozásig és az értékelésig. Tér és Társadalom, 15. 2001. 2. 25-69. p

A minta RAP a felsorolt célok többségét közvetlenül megvalósította. A program kialakítása, pontosabban a minta RAP eredményeinek figyelembevételével annak átalakítása, már a kísérleti projekten kívül történik.

A projekt alap célja - a fentiek alapján -, hogy segítse a Közép-dunántúli régióból érkezỏ projektjavaslatok integrálását az EU Strukturális Alapok felhasználása érdekében készülő NFT Regionális Operatív Programjába és Ágazati Operatív Programjaiba. A feladat az volt, hogy az összegyüjtött projektjavaslatokból egy rendszerezett, rangsorolt projektadatbázis, uniós szakkifejezéssel 'project pipeline' készüljön. Az uniós regionális politikában egy olyan feladatmegosztás érvényesül, miszerint az Európai Bizottság fogadja el a területfejlesztési programokat, míg a programokon belül a projektek kiválasztását - a helyi és a regionális szereplökkel kialakított partnerség keretében - a tagállamok végzik el.

A Közép-dunántúli régió területfejlesztési programja biztosította a minta RAP szellemi hátterét. A stratégiai program jövöképe szerint a Közép-Dunántúl az innováció régiójává válik. A stratégia megvalósítását a régió a versenyképes társadalmi és gazdasági szerkezet, regionális egyensúly, a fenntartható fejlődés és az uniós csatlakozásra történỏ felkészülés célkitüzéseinek teljesítésén keresztül kivánja elérni. A minta RAP a helyi igények és prioritások világos és határozott kifejezése, amely hozzájárulhat a nemzeti szintủ regionális politika formálásához.

A Közép-dunántúli projekt adatbázis összeállítása során felhasználásra kerültek a korábbi hasonló hazai kezdeményezések: az oszták-magyar-szlovák hármashatár menti közös területfejlesztési stratégia, SAPARD kistérségi programok, más régiók kezdeményezései, kiemelten a Nyugat-dunántúli régió 'KEZDET' projektje.

A projektgyújtés folyamata több munkafázist ölelt fel: kérdőiv készítése és tesztelése, a lekérdező biztosok felkészítése, a lekérdezésre kerülö szervezetek listájának ósszeállítása, információs napokon az érdekeltek figyelmének felkeltése és a kérdőív kitöltésére való felkészülés segítése, a kérdőívek lekérdezése.

A projektjavaslatok elsödleges értékelése olyan stratégiai szempontokat vett figyelembe, mint a javaslat hatása a régió stratégiai programjára, illetve a régióban élők számának nagyságára. Az egyes javaslatok pályázatszerü értékelése is megtörtént, mely során a projekt kidolgozásának színvonala, a pénzügyi fenntarthatóság, az innovativitás és a pályázó felkészültségének színvonala került mérlegelésre.

A projektadatbázisba a projekt időkeretén belül 157 javaslat érkezett, melyből 155 alkalmas a ROP, vagy valamely SOP 'Project pipeline'-jába kerülésre. Az alábbi táblázat tanúsága szerint a javaslatok többsége az Európai Regionális Fejlesztési Alap (European Regional Development Fund - ERDF) által támogatható akciókra irányul, nagy hányadát tekintve a nemzeti ROP keretei között megvalósithatóan. 53 projekt kapta a legmagasabb " $\mathrm{A}$ " minősitést a regionális programra és 29 a projekt régió teruletére, népességszámára gyakorolt hatás értékelése során (5. táblázat). Ezek a számok a minta RAP sikeres megvalósitását jelzik, hiszen kulcsfontosságú projekteket határozott meg a régió továbbfejlődésének biztosítása, a megfogalmazott stratégiai célkitüzések megvalósitása érdekében. A ROP keretei között 16, 
mig a SOP-ok esetében további 5 projekt kapott 'AA'-s minősítést. A késỏbbiekben ezek kiemelt figyelmet érdemlö projektek lehetnek a régióban.

Természetesen a minta RAP során kialakult lista nem egy zártvégủ adatbázis, hanem egy folyamatos munkakapcsolat kezdete a KD RFÜ, a partnerszervezetek és a potenciális projektgazdák, kedvezményezettek között.

A minta RAP sikeres volt mind a projektjavaslatok generálását, mind azok rangsorolását tekintve.

A folyamat hiányosságait is célszerü azonban számba venni a további alkalmazások érdekében:

- A minta RAP felmérési, projektgyủjtési időszaka a nyári szabadságok derekára esett, amely jelentősen csökkentette a potenciális projektgazdák elérhetőségét;

- Néhány szervezet alulreprezentált a minta RAP-ban, illetve a stratégiai program néhány intézkedésére nem érkezett projektjavaslat (ipari integrációk támogatása, speciális felkészítési programok, EU-s helyi szervezeti struktúrák és múködési mechanizmusok modell-adaptációja);

- Az innováció régiójává válást segítő felsőoktatás fejlesztése mérsékelten jelent meg a javaslatok között;

- A lekérdezések elökészítése, a partnerszervezetekkel történő kommunikáció is mutatott hiányokat (pl. megbízólevél hiánya a lekérdezésekhez).

\section{TÁBLÁZAT}

A projektjavaslatok támogatási csoportok szerinti megoszlása (db)

(Distribution of Project Proposals by the Origin of Funds)

\begin{tabular}{|c|c|c|c|c|c|c|c|c|c|}
\hline \multirow{2}{*}{ Támogatási kör } & \multirow{2}{*}{ Összesen } & \multicolumn{3}{|c|}{ Ebböl: } & \multicolumn{2}{|c|}{$\begin{array}{l}\text { Régió számára } \\
\text { fontos }\end{array}$} & \multicolumn{3}{|c|}{ Térségi hatás } \\
\hline & & ROP & SOP & $A$ & B & $\mathrm{C}$ & $A$ & B & C \\
\hline EAGGF & 16 & 16 & 0 & 2 & 10 & 4 & 1 & 1 & 14 \\
\hline ERDF & 84 & 70 & 14 & 38 & 34 & 12 & 20 & 38 & 26 \\
\hline ESF & 16 & 13 & 3 & 8 & 6 & 2 & 7 & 5 & 4 \\
\hline $\begin{array}{l}\text { Strukturális Alapok } \\
\text { össz. }\end{array}$ & 116 & 99 & 17 & 48 & 50 & 18 & 28 & 44 & 44 \\
\hline $\begin{array}{l}\text { Kohéziós } \\
\text { Alap/ISPA }\end{array}$ & 11 & 0 & 11 & 5 & 6 & 0 & 1 & 7 & 3 \\
\hline $\begin{array}{l}\text { Nemzeti } \\
\text { célelőirányzatok }\end{array}$ & 20 & 0 & 20 & 0 & 10 & 6 & 0 & 2 & 18 \\
\hline $\begin{array}{l}\text { Megyei ter.fejl.-i } \\
\text { tám.-ok }\end{array}$ & 8 & 0 & 8 & 0 & 3 & 3 & 0 & 2 & 6 \\
\hline $\begin{array}{l}\text { Mindösszesen } \\
\text { Megoszlás (\%) }\end{array}$ & 153 & 99 & 56 & $\begin{array}{l}53 \\
256\end{array}$ & 69 & 27 & 29 & 35 & $\begin{array}{l}71 \\
458\end{array}$ \\
\hline Helyi finanszírozás & 2 & $\begin{array}{c}03,9 \\
0\end{array}$ & $\begin{array}{c}50,1 \\
0\end{array}$ & $\begin{array}{c}35,0 \\
0\end{array}$ & $\begin{array}{c}40,3 \\
0\end{array}$ & $\begin{array}{c}10,1 \\
0\end{array}$ & $\begin{array}{c}10,1 \\
0\end{array}$ & 0 & 2 \\
\hline
\end{tabular}

Forrás: Callanan-Lados (2001).

A fenti problémák döntően a projekt rövid átfutási idejébỏl, gyors elökészitéséböl fakadnak, melyek a minta RAP folyamattá alakításakor (Közép-Dunántúl), illetve adaptálásakor (többi régió) feloldhatók. 
A minta RAP fontos üzeneteket hordoz valamennyi régió irányába annak érdekében, hogy minden régió azonos módszertannal készítse elö hozzájárulását, inputjait az NFT keretei között készülő ROP-hoz.

\section{A jövő kihívásai a hazai területi tervezésben}

A csatlakozással lezárul a több mint egy évtizedet átölelö hosszú menetelés a hazai területi tervezésben. Módszertanában megújulva, a helyi szinttől a nemzeti szintig elkészültek az átfogó 10-15 évet vagy akár hosszabb időtávot is átfogó koncepciók és stratégiák. Napjainkban már készülnek a nagy ívü jövőképeket az EU tervezési ciklusokhoz igazító tervek és stratégiai programok, az azok megvalósítását aprópénzre váltó, az aktuális helyi-megyei-regionális-nemzeti költségvetésekben megjelenő operatív programok. Ez a tervezési lánc minden területfejlesztési szereplö - a kormányzati politikusoktól és hivatalnokoktól, a tervezőkön és kutatókon át a regionális-megyei-kistérségi-helyi aktorokig számára egy folyamatos és intenziv tanulási folyamatot jelentett és jelent ma is.

A különböző szerepkörökben - megbízó, tervezö, megvalósító - a területfejlesztésben érdekeltté válók száma napjainkra több ezerre tehetó. Ök találkoztak és tanulták meg közvetlenül, mit jelent a stratégiai szemlélet a területfejlesztésben, milyen eszköztárral - belső és külső helyzetelemzés, SWOT elemzés, forgatókönyvek, jövőképépítés, programozás - építhetök fel a különböző szintủ területi stratégiák, gyakorolták a partnerségi szerepeket a tervezési folyamatokban. Ebben a folyamatban jelentős szerepe volt a tervezéssel párhuzamosan történö folyamatos tanulásnak ('learning by doing'). Ugyanakkor megindult ennek a tudásbázisnak a megalapozása, szervezett átadása is:

- oktatási háttér kialakulása a felsöoktatásban (komplex területfejlesztési képzés és különböző egyedi stúdiumok a föiskolai, egyetemi és doktori iskolai programokban) és a felnött képzésben (Az EU által támogatott és nemzeti szinten szervezett felkészítỏ programok ['in job training']),

- Európa Tanulmányok Központja hálózat, illetve más szervezetek által szervezett training programok stb.; valamint

- tankönyvek, szakkönyvek sokasága jelent meg a témához kapcsolódóan.

Magának a tervezési láncnak a többi eleme is feszültségeket hordoz, amelyek oldására az alábbi alapelvek fogalmazhatók meg (Grosz-Lados-Rechnitzer-Tóthné Hermann 2000):

- Egyértelműen meg kell határozni a különféle területi szintek, illetve az ágazatok területfejlesztés kompetenciáját, azok egymásra épülését és kapcsolatát.

- A területi szemlélet jelenjen meg az ágazati tervekben, részben a területi szintek visszacsatolásával, részben az egyértelmü ágazati elképzelések érvényesítésével.

- A tervezés az egyes területi szinteken azonos metodikával, tematikával és iteratív jelleggel történjen, időben ütemezve és összehangolva. 
- A tervezés rendszere szorosan épüljön az Európai Unióban kialakult gyakorlatra és technikákra.

- Új eljárásokat kell kidolgozni a társadalmi, a szakmai szereplök minél szélesebb köre véleményének beépítésére a tervezésbe, illetve a tervek, programok egyeztetésében a területfejlesztés szereplőinek aktivizálására.

- A tervezés és a programozás hatékonyságát (egyben komolyságát) egyértelmüvé csak a decentralizált fejlesztési források meghatározásával és biztosításával lehet növelni. Garanciát kell adni a területi szinteknek, hogy a középtávú tervezési és programozási időszakban biztosítva lesznek központi források, ha azokhoz meghatározott - kisebb mértékủ - területi forrást is biztosítani képesek.

- Mindezek érdekében egy önálló tervezési törvény kidolgozása szükséges, amely

- rögzíti a különféle szinteken (országos, ágazati, regionális, megyei, kistérségi, települési) kidolgozandó tervek típusait és azok tartalmi követelményeit,

- meghatározza a tervek kapcsolatrendszerét, egymásra épülését,

- elöírja a tervek időhorizontját, elfogadási rendjét, korszerüsitésének módját,

- meghatározza a tervek társadalmasításának módját,

- rendelkezik a tervek megvalósitásának rendszeréről és azok értékeléséről.

$\mathrm{Az}$ eddigi folyamatok kevéssé tekintettek túl a tervezésen. Lezárul egy nagy ciklus és ủjabb kezdödik. Amivel adósok vagyunk, az a mérés. Milyen hatásai vannak a megfogalmazott stratégiáknak, programoknak a hazai vagy akár a középeurópai és európai területi fejlödésre? Miképpen hatnak egymásra a különböző szinteken megfogalmazott tervezési dokumentumok? A területfejlesztési szakemberek számára ez a közeljövő egyik legnagyobb kihívása. Ennek kimunkálásában, a tervezési lánc fejlesztésében napjainkig elvégzett munkákhoz hasonlóan, a NYUTI továbbra is úttörö szerepet igyekszik betölteni.

\section{Jegyzetek}

${ }^{1}$ Pontosabban az 1990. évi LXV. A helyi ơnkormányzatokról szóló tơrvény kialakításakor, a megyei onkormányzatok feladat- és hatáskőreinek jelentős mérséklése során a területfejlesztés nem került a megye kötelezően ellátandó feladatai közé.

${ }^{2}$ Nem maga a stratégiai tervezés volt újdonság, hiszen az a mikrogazdaságban, a vállalati tervezésben már évtizedek óta használt módszer volt, hanem a kơzszférában és a területfejlesztésben tơrténö alkalmazása számított újdonságnak a nyolcvanas évek végén, a kilencvenes évek elején.

${ }^{3}$ A Csornai KSH kistérség a TEKI 2001-2003 kőzötti időszakban az átmeneti kategóriába került. Ez azt jelenti, hogy 2004-tỏl mindenképpen kikerül a kedvezményezett kistérségek köréböl.

${ }^{4}$ Az 1993-ban indított, 10 millió ECU összegü l. Phare Teruletfejlesztési Program három témakört olelt fel: 1. A hazai teruleti politika továbbfejlesztését (Területfejlesztési tơrvény megalapozása); 2. Kísérleti fejlesztési programok végrehajtását (Kísérleti megyei területfejlesztési tanács és ügynơkség létrehozása és múkődtetése Borsod-Abaúj-Zemplén és Szabolcs-Szatmár-Bereg megyében); 3. A települések közőtti együttmúkơdés serkentése (széles partnerségi alapokon létrejött településszövetségek). 
${ }^{5}$ A legutóbbi két és a jelenlegi EU tervezési periódust tekintve, azok időtartama ciklusonként egy évvel növekedett: 1989-1993: 5 év, 1994-1999: 6 év és 2000-2006: 7 év.

${ }^{6}$ A Regional Science Association (RSA) 1994. évi Groningenben (Hollandia) megrendezett Európa Kongresszusán jelentek meg nagy számban olyan tanulmányok, amelyek a forgatókơnyv elemzési technikára épultek. A módszer hazai területi kutatásokban tơrténó alkalmazását Enyedi György alapozta meg a kilencvenes évek közepén, három szcenáriót vázolva a hazai területi fejlődésre (Enyedi 1996): 1.) A polarizált regionális fejlöđés forgatókőnyve; 2.) A közepesen koncentrált regionális fejlödés forgatókönyve; 3.) A dekoncentrált regionális fejlődés forgatókőnyve.

${ }^{7}$ Zala megye is támogatásáról biztositotta a régió program készítését. Mivel a megye a Dél-dunántúli régióban is érdekelt volt, ezért a megyei szintủ tervezési folyamat már korábban elindult a Pylon Kft. vezetésével.

${ }^{8}$ Az már egy másik kérdés, hogy a koncepció hat prioritásából pénzügyileg csupán kettő vált valóban megvalósithatóvá. Ennek oka, hogy a Terủletfejlesztési Célelöirányzat (TFC) és a TEKI felhasználását kőzpontilag szabályozták. Ez pedig pl. csak 2001-től vette fơl a támogatható célok kơzé a humánerơforrás-fejlesztést, amely a Györ-Moson-Sopron megyei területfejlesztési koncepció egyik kulcsprioritása volt.

9 184/1996 (XII.11.) Korm. rendelet A területfejlesztési koncepciók és programok, valamint a területrendezési tervek egyeztetésének és elfogadásának rendjéröl.

${ }^{10} \mathrm{Az}$ együttmükődés sikere a résztvevökơn múlott, de a háttérben a megbizó MTT tudatos döntése húzódott meg. A NYUTI úgy nyerte el a tervezési megbizást, hogy az MTT kérte a megyei szervezetek bevonását a projekt megvalósitásába. Természetes partnerként kinálkozott a korábbi években már a megyében kistérségi szinten aktiv területfejlesztési szerepet vállaló RVA, aki szintén pályázott a koncepció elkészítésére.

" Az egyes megyékben lista készült a megye híres embereiről: országgyülési képviselók, jelentősebb intézmények és vállalkozások vezetöi, kiemelkedő megyei személyiségek.

${ }^{12}$ Sokan még nem érezték a súlyát a koncepciónak Veszprém megyében. Míg Győr-Moson-Sopron megyében deklaráltan már az első TFC és TEKI pályázati kiírástól a megyei koncepció volt a dőntések iránytüje, addig Veszprém megyében az elhúzódó tervezési folyamat miatt ezt a területfejlesztés szereplöi nem érzékelték. A dolog fontosságára akkor ébredtek rá, amikor már a második pályázati ciklus leteltével a megye egyes térségei úgy érzékelték, hogy rendszeresen a forrás nélkül maradó pályázók kőzőtt helyezkednek el. İgy történt, hogy bár a kötelező egyeztetési eljárás során írásos véleményt nem adtak, a megyei ơnkormányzatnak a koncepció elfogadását tárgyaló közgyülése elött egy hónappal Pápa polgármestere és a Pápai Kistérség fejlesztési Társulás vezetöje személyesen mondta el a tervezőknek, hogy a tervezési dokumentum egyes fejezeteiben hol, mivel kellene szerepeltetni Pápát és térségét. Lényegében erre az időszakra tudatosult bennük, hogy a koncepció elfogadását követóen a TFC és TEKI pályázatok elbirálásánál a koncepcióban megfogalmazottak lesznek irányadóak.

13 A területfejlesztési koncepciók, programok és rendezési tervek tartalmi kővetelményeiről szóló 18/1998. (VI.25.) sz. KTM rendelet.

${ }^{14}$ A NYUTI 1996. január 16. óta a - No C.C.R. HUN-20860 számon - Phare/Tacis regisztrált tanácsadó szervezete Brüsszelben a regionális fejlesztések és regionális politika témakỏrében.

${ }^{15}$ A tơrvény csak két tervezési régió esetében irta elö a tanács megalakitásának kotelezettségét: Budapesti Agglomeráció Fejlesztési Tanács, Balaton Fejlesztési Tanács (1996. évi XXI. tv. 15.§. 2/a-b. bek.). A tơrvény 1999. évi módosítása rögzítette a statisztikai régiók ósszetételét, hogy azok átfedés nélkül fedjék le az országot (1999. évi XCII. tv. 7.§. 2. bek.). A két fejlesztési régió kơzül csak a Balatont nevesitette, ugyanakkor lehetóséget biztositott a speciális érdekeket képviselö tơbb megyét, illetve régiót érintő onkéntesen szerveződô térségi fejlesztési tanácsok létrehozáára. A Balatont ezek sorában említi a tơrvény (1999. évi XCII. tv. 5.§.).

${ }^{16}$ Ebben az időszakban hiányzott a harmadik fél, az osztrákok aktiv részvétele a projektben. Ennek az oka az volt, hogy Ausztriában még nem kezdődott meg az INTERREG III program tervezése az érintett tartományokban (Alsó-Ausztria, Bécs, Burgenland). Így az 1999. végére elkészült 
dokumentum valójában csak magyar-szlovák kőzős stratégia. Az osztrák fél 2000. végétöl kezdett aktivizálódni, mivel az INTERREG III csatornái csupán 2002-töl nyílnak meg. Jelenleg JORDES+ (Joint Regional Development Strategy for the tri-border area of Austria, Hungary and Slovak Republic) néven kezdeményeznek kozzös tervezési projektet a hármashatár térségére.

17 A fentieken túl a NYUTI látta el a projekt titkársági és logisztikai feladatait is (workshopok szervezése, sokszorosítás, tolmácsolás, dokumentumok, prezentációs anyagok fordítása, külfooldi szakértók helyi munkafeltételeinek biztosítása).

${ }^{18}$ Extrém példán keresztủl érzékeltethetö ez a helyzet. A külfơldi szakértök egy része azért volt felelös, hogy elökészitse és lebonyolítsa azokat a helyi és ágazati workshopokat, amelyek feltárják a vizsgált térség jellemzöit, szạkségleteit, és elindítja a projektgenerálás folyamatát. Munkájuk zárását a workshopokról készitett jelentés jelentette. Volt olyan szakértö, aki ezt nem teljesítette, mert már letelt a számára biztositott 20 szakértöi nap!

${ }^{19}$ A WMEB gyakorlatában ez azt jelentette, hogy a szerződö fél, ha a projekt átfutási ideje al att havonta kíván számlázni, akkor 30\%-kos részesedéssel számolt, ha azonban csak a projekt végén állított ki számlát, akkor 25\%-kal. (Ez utóbbi esetben fejeződött ki az, hogy nem a WMEB, hanem a szerződö fél elöfinanszírozta a projektet.)

${ }^{20}$ A NYUTI ezt nem vállalta fel a hármashatár stratégia keretében.

${ }^{21}$ 18/1998. (VI.25.) KTM rendelet A teruletfejlesztési koncepciók, programok és teruletrendezési tervek tartalmi követelményeiröl.

22 The New Programming period 2000-2006: methodological working papers - Working Paper 1 Vademecum for Structural Funds Plans and Programming Documents Objective 1, 2, and 32000 2006.

${ }^{23}$ 24/2001. (IV. 20.) OGY Határozat A teraletfejlesztés kedvezményezett térségeinek lehatárolásáról.

24 The New Programming period 2000-2006: methodological working papers - Working Paper 2. The Ex-Ante Evaluation of the Structural Funds interventions.

${ }^{25}$ A Vision Planet előzetes változatának fordítása megjelent a TÉT 1999. 1-2. számában, 2001. elején pedig a végleges dokumentum jelent meg magyarul a NYUTI forditásában és a VÁTI kiadásában.

\section{Irodalom}

Callanan, B.-Lados M. (2001) Közép-dunántúli Regionális Cselekvési Terv Modell. Shannon-Györ, MTA RKK NYUTI. Kézirat.

Enyedi Gy. (1996) Regionális folyamatok Magyarországon az átmenet idöszakában. Budapest, Hilscher Rezsö Szociálpolitikai Egyesület.

Faragó L. (2000) Teruleti tervezés az európai integráció tủkrében. - Horváth Gy,-Rechnitzer J. (szerk.) A régiók szerepe a bõvülö Európai Unióban. Pécs, MTA RKK. 149-162. o.

Forman B. (2000) Regionális politika az Európai Unióban. Területfejlesztési szakkönyvek. Budapest, VÁTI.

Grosz A.-Lados M.-Rechnitzer J. (szerk.) (1999) A Balaton Kiemelt Uddülökörzet területfejlesztési koncepcioja-1. melléklet A hivatalos egyeztetési eljárás során beérkezett vélemények feldolgozása. NYUTI Közlemények 88. Györ, MTA RKK NYUTI.

Grosz A.-Lados M.-Rechnitzer J.-Tóthné Hermann J. (2000) A területfejlesztési koncepciók és programok összehasonlitó értékelése. NYUTI Közlemények 116. Györ, MTA RKK NYUTI.

Grosz A.-Lados M. (2001) A Közép-dunántúli régió teruiletfejlesztési programja. Györ-Székesfehérvár, MTA RKK NYUTI.

Horváth Gy. (1998) Európai regionális politika. Budapest-Pécs, Dialóg Campus.

Hrubi L. (1997a) A megyei fejlesztési koncepciók (Összegzés), - Tér és Társadalom. 3. 79-86. o.

Hrubi L. (1997b) Új vonások a Baranya megyei területfejlesztési koncepcióban. - Tér és Társadalom. 3. 87-92. 0 .

Lados M. (1997) Önkormányzati gazdálkodás és a területfejlesztés az Északnyugat-Dunántúlon. - Tér és Társadalom. 1. 197-217. o.

Lados M. (2001a) A Nyugat-dunántúli régió terïletfejlesstési programja. Györ, MTA RKK NYUT1.

Lados M. (2001b) Györ-Moson-Sopron megye területfejlesstési programja. Györ, MTA RKK NYUTI. 
Lados Mihály: A területi tervezés kihívásai a kilencvenes években Magyarországon:

A területfejlesztési stratégiák kialakitásáról a programozásig és az értékelésig. Tér és Társadalom, 15. 2001. 2. 25-69. p

68 Lados Mihály

TÉT XV. évf. 2001 - 2

Lados M. (2001c) Managing Regions in Hungary. Konferencia elöadás. Regional Policies in Europe: The Knowledge Age: Managing Global, Regional and Local Interdependencies. Nemzetközi Szimpózium - Eisenerz (Ausztria), 2001. szeptember 21-23.

Lados M. - Rechnitzer J. (1997a) Az Északnyugat-Dunántúl területfejlesztési stratégiája. - Tér és Társadalom. 1.219-269. o.

Lados M. - Rechnitzer J. (1997b) The Experiences of Strategic Planning in Hungary. Konferencia elöadás. RSA 37. Európa Kongresszus. Róma, 1997. augusztus 26-29.

Rechnitzer J.-Sas B. (1987) Térszerkezeti vizsgálatok az Észak-Dunántúlon. Regionális Kutatások Központjának Kutatási Eredményei 6. Pécs, MTA RKK.

Rechnitzer J. (szerk) (1988) A Rábaköz térszerkezete. Csorna-Kapuvár, MTA RKK ÉDO.

Rechnitzer J. (1990) A nyitatt határ. Györ-Bécs, MTA RKK ÉDO.

Rechnitzer J. (1991) Az innováció fogadás feltételei Vas megye hátrảnyos helyzetü térségeiben (Regionális esettanulmány). Vasvár, Vas Megyei Elmaradott Térségi Önkormányzatok Szövetsége.

Rechnitzer J. (1994) Fejezetek a regionális gazdaságtan tanulmányozásához. Györ-Pécs, MTA RKK.

Rechnitzer J. (szerk.) (1995) Györ-Moson-Sopron megye területfejlesztési stratégiája. - I. kötet A megye Európában és a magyar térszerkezetben. NYUTI Közlemények 10/I. Györ, MTA RKK NYUT1.

Rechnitzer J. (1998) A területi stratégiák. Budapest-Pécs, Dialóg Campus.

Szörényiné Kukorelli 1. (1997a) A kistérségek gazdasági és társadalmi jellemzői és trendjei ÉszakDunántúlon. - Tér és Társadalom. 1. 147-191. o.

Szörényiné Kukorelli 1. (1997b) Fejlesztési koncepciók a kistérségek számára (Összegzés). - Tér és Társadalom. 3. 93-100. o.

Vision Planet - A közép-európai, a Duna menti és az adriai térség integrált területfejlesztési stratégiája (Irányelvek és fejlesztéspolitikai javaslatok). (200I) Budapest, PHARE-VÁTI.

\section{CHALLANGES OF THE SPATIAL PLANNING IN HUNGARY IN THE 1990S: \\ FROM REGIONAL STRATEGIES TO PROGRAMMING AND IMPACT ANALYSIS}

\section{MIHÁLY LADOS}

During the socio-economic transformation of Hungary, planning including spatial planning has become a symbol of the former planning economy. At the start of the Transition, the institutional system of planning was abolished both at national and county level.

Hungary has become a joint member of the European Union (EU) since 1991. Based on Phare aid program, Hungary has started the preparation for accession. A special program was set up to promote the EU conform transformation of the Hungarian regional policy. Professionals recognised that the EU regional policy utilises planning significantly, especially the methodology of strategic planning. As in whole Europe, the 1990 s became the decade of the renaissance of planning in Hungary.

During this decade we have started from the preparation of long tern visions and strategies and has reached the phase of operative programmes. This process has run along the different spatial levels of the Hungarian regional policy defined in the Act XXI on Regional Development and Physical Planning: national, regional, county, small region.

Among the increasing number of actors in regional and spatial planning Centre for Regional Studies (RKK) including West Hungarian Research Institute (NYUTI) has played a leading role adopting and developing new methods in planning. This paper provides a special view of this process through the glasses of NYUTI based on the planning projects has been implemented by NYUTI during this period.

The paper is dealing with county, regional, national and transnational plans. The core of the study is that what was/are the new challenges of spatial planning for Hungary according to 
EU accession. What role has NYUTI played in dissemination of the innovative methods in spatial planning in Hungary?

The paper discusses this process in four chapters. The first chapter describes the changing needs for regional studies at the end of the 1980s. The basis of the second chapter is the requirements of the renewal of Hungarian spatial planing according to EU accession and Maastricht principles, and the need for foundation of strategic planning. The third chapter deals with planning in consorcium and the transnationalisation of planning. The forth chapter discusses programming as a new challenges of the pre-accession period.

Evaluating this process, we can conclude that the described actions did not look beyond planning until now. A planning cycle will close and a new will start soon. We miss the monitoring and the impact analysis of plans. What impacts are the planned strategies and programs on the national, Central European and European regional development? What synergies can be find among plans prepared in different spatial levels? Monitoring and impact analysis will be the most important challenge for Hungarian planners in near future. We believe that NYUTI will play a pioneer role to work out and test the new methods as it did in the last ten years. 